\title{
The Conservational State of Coastal Ecosystems on the Mexican Caribbean Coast: Environmental Guidelines for Their Management
}

\author{
Mayrene Guimarais ${ }^{1, *(1)}$, Adán Zúñiga-Ríos ${ }^{2}$, Cesia J. Cruz-Ramírez ${ }^{1}$, Valeria Chávez ${ }^{1}$ (), Itxaso Odériz ${ }^{1}$, \\ Brigitta I. van Tussenbroek ${ }^{3}$ and Rodolfo Silva ${ }^{1, *(D)}$ \\ 1 Instituto de Ingeniería, Universidad Nacional Autónoma de México, Mexico City 04510, Mexico; \\ ccruzr@iingen.unam.mx (C.J.C.-R.); vchavezc@iingen.unam.mx (V.C.); ioderizm@iingen.unam.mx (I.O.) \\ 2 Posgrado en Ciencias del Mar y Limnología, Universidad Nacional Autónoma de México, \\ Mexico City 04510, Mexico; adanzrs@yahoo.com \\ 3 Unidad Académica de Sistemas Arrecifales-Puerto Morelos, Instituto de Ciencias del Mar y Limnología, \\ Universidad Nacional Autónoma de México, Puerto Morelos 77580, Mexico; vantuss@cmarl.unam.mx \\ * Correspondence: mguimarais@yahoo.es (M.G.); rsilvac@iingen.unam.mx (R.S.)
}

\section{check for} updates

Citation: Guimarais, M.; Zúñiga-Ríos, A.; Cruz-Ramírez, C.J.; Chávez, V.; Odériz, I.; van Tussenbroek, B.I.; Silva, R. The Conservational State of Coastal Ecosystems on the Mexican Caribbean Coast: Environmental Guidelines for Their Management. Sustainability 2021, 13, 2738. https:// doi.org/10.3390/su13052738

Academic Editor: Marcello Di Risio

Received: 25 January 2021

Accepted: 26 February 2021

Published: 3 March 2021

Publisher's Note: MDPI stays neutral with regard to jurisdictional claims in published maps and institutional affiliations.

Copyright: (c) 2021 by the authors. Licensee MDPI, Basel, Switzerland. This article is an open access article distributed under the terms and conditions of the Creative Commons Attribution (CC BY) license (https:/ / creativecommons.org/licenses/by/ $4.0 /)$.

\begin{abstract}
The accelerated rate of environmental degradation of the Mexican Caribbean coast is alarming. In this work, spatial analysis procedures were applied to study relationships among wave and wind climates, water quality, and environmental degradation of the principal coastal ecosystems. We found an increasing North-South gradient in the preservation state of the coastal ecosystems, related to the degree of anthropization of the coastline. In the north, all analysed stressors exert high pressure on coral reefs, seagrass meadows, mangroves, and dunes, and cause chronic coastline erosion. The coastal ecosystems of the central and southern regions are more mature and healthier, and the most significant stressor is reduced water quality. The north has been most hit by high-intensity hurricanes, the frequency of which has increased in the Mexican Caribbean over recent decades. The status of conservation of the ecosystems, added to the long-term intensification of environmental pressures, particularly high-intensity hurricanes, will induce further deterioration if a coordinated management scheme is not adopted by decision-makers. To ensure effective coordinated management, plans should be made on a regional scale using shared guidelines. Spatial analysis procedures aid in prioritizing and adapting the shared guidelines depending on the identified major stressors and the preservation state of each region in the Mexican Caribbean.
\end{abstract}

Keywords: coastal anthropization; coastal erosion; ecosystems conservation; environmental pressures; fragmentation; water quality

\section{Introduction}

The Caribbean Sea is a unique biogeographic region, among the top five hotpots in the world for marine biodiversity. It is home to approximately 500 fish species, has $12 \%$ of the world's reefs, and its Mesoamerican Reef System is the second largest barrier reef in the world [1]. The Mexican Caribbean has $\approx 900 \mathrm{~km}$ of coastline (insular and continental), with various interacting ecosystems. The environmental goods and services provided by these coastal ecosystems are numerous; provisioning (e.g., fisheries, desalinization/freshwater, timber); supporting (e.g., biodiversity services through coastal habitats); regulating (e.g., climate regulation, regulation of nutrient fluxes), and cultural (e.g., tourism, recreation, education) [2]. Although the Caribbean region has 15 Natural Protected Areas (NPAs) [3] and nine Priority Marine Regions (PMPs) for conservation [4], many of the ecosystems have been deteriorating for several decades [5].

The Mexican Caribbean is subject to multiple stresses [6,7], including major anthropic development on the coast, driven by the rapid growth in the tourism industry that began 
in Cancun in the north, in the early 1970s [8]. Gradually, this development has spread southward [9]. On the other hand, the increasing intensity of storms and hurricanes [10] have been exerting pressures on the coastal ecosystems already under pressure from human development. Recent massive arrivals of pelagic Sargassum spp. [11,12] into the Mexican Caribbean since late 2014 [13-15] have exacerbated the pressure on the coastal ecosystems [16], and subsequently, in the incomes generated by tourism [15,17].

Knowledge about climate-determined environmental changes worldwide and their effects on coastal and marine ecosystems is incomplete [18]. In the Mexican Caribbean, there are local reports on the decline in area and health of the reefs, and fisheries productivity [6,19], and loss or deterioration of seagrass meadows [16,20,21], mangroves [22,23], and dunes $[24,25]$. However, a comprehensive analysis of the state of conservation of the coastal ecosystems along the whole stretch of Mexican Caribbean coastline and their main environmental pressures is lacking. Such analysis is necessary in order to establish measures for integrated management and/or their ecosystems restoration strategies to safeguard the ecosystem services they provide to us humans.

In this paper, we hypothesize that there is a north to south gradient in the state of preservation of the coastal ecosystems of the Mexican Caribbean, related to physicalchemical stressors and the degree of coastal development. Environmental guidelines are suggested to improve the integrated coastal management of the Mexican Caribbean coast.

\section{Materials and Methods}

The study area is part of the coast of Quintana Roo state, in the southeast of Mexico, between the $17,769^{\circ} \mathrm{N} ;-85,218^{\circ} \mathrm{W}$ and $21,932^{\circ} \mathrm{N} ;-88,288^{\circ} \mathrm{W}$, Figure 1 .

\subsection{Coastal Ecosystems}

A bibliographic review was made searching the Scopus Database using the keywords seagrass, mangrove, reef coral and dune, Mexican Caribbean, and Quintana Roo, as well as names of specific authors renowned for their work in this region. Bibliographic references in some of the articles produced useful information from journals not indexed in the abovementioned database. In all cases, only those papers that evaluated the state or changes in the state of an ecosystem were reviewed and considered in this analysis. Geospatial vectors (Shapes) of the mangrove [26], seagrass, and coral reef [27] ecosystems were obtained from the CONABIO geoportal.

The information on each site was categorized to discern a possible gradient in the state of ecosystem preservation from north to south. Coral reefs were classified according to the development or coral maturity stages following Argüelles-Jiménez et al. [28]. Seagrass meadows were classified based on changes in the relative abundance of climax and earliersuccessional species, following observations in van Tussenbroek [20], van Tussenbroek et al. [21], and Ferdie \& Fourqurean [29]. The areas of mangroves classified as disturbed and undisturbed following CONABIO [26] were spatially overlaid to the NPAs in a Geographical Information System (GIS) [3] and regions (Northern, Central and Southern) to determine their distribution. The surface of the dunes was digitized from orthophotos, 1995-2004, and from the most recent satellite images from Google Earth (2015-2020). These periods in the digitization of dunes were long because for one year there are no images with full coverage of the state's coast. The images from both periods were checked and corrected in Google Earth to reduce error and to avoid including bodies of water, mangrove or vegetation as part of the dunes. The areas of the polygons obtained were compared, by region and by Natural Protected Area (NPA), to identify those with most change in their extension. The evolution of the coastline between 1970/81 and 2015 was obtained from Valderrama et al. [30]. 


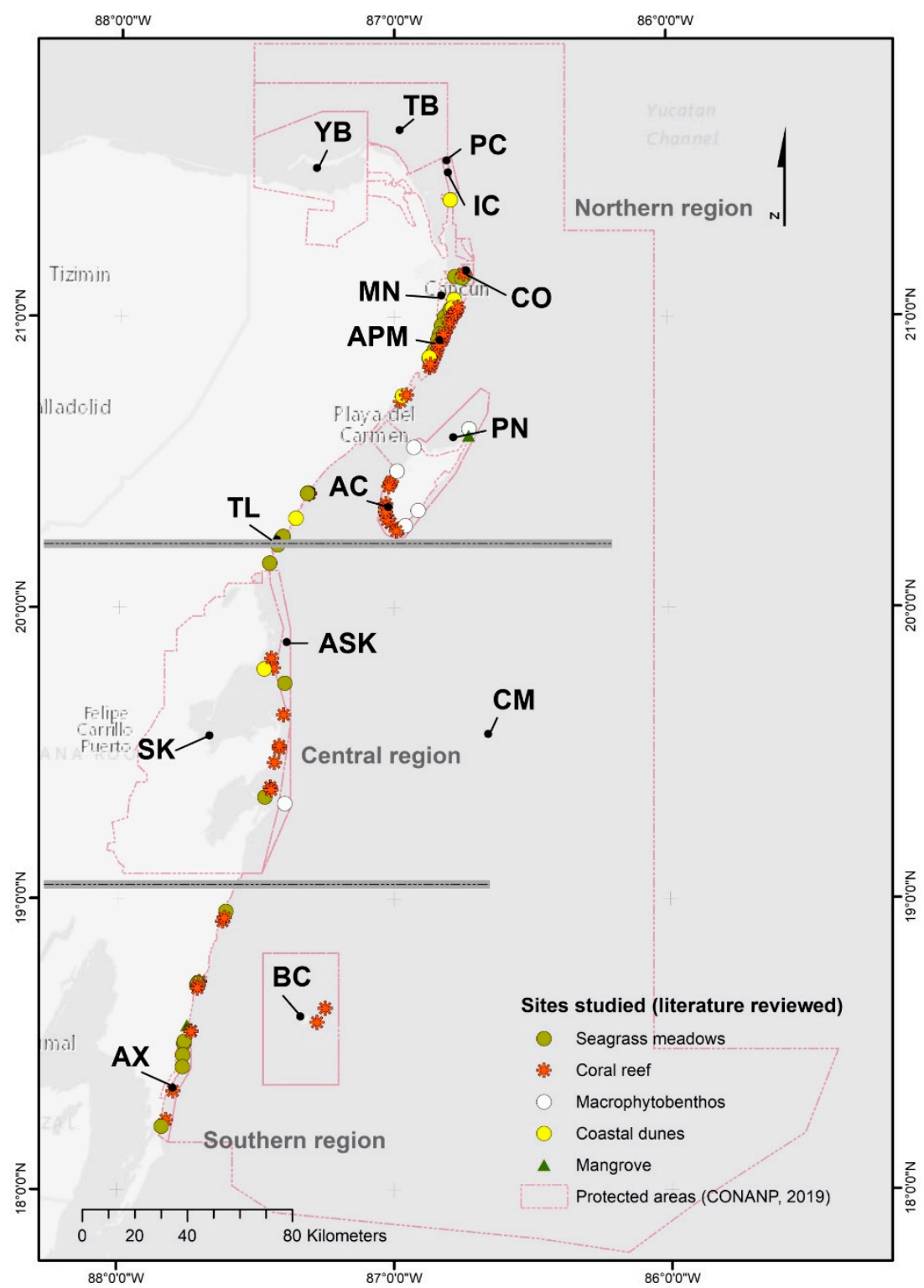

Figure 1. Studied sites on the coast of the Mexican Caribbean (See Table 1 for abbreviations).

The spatial integrity of the coral reef and mangrove ecosystems was obtained from Equation (1), which is an indicator of the degree of fragmentation of the ecosystem and assumes that large continuous biotopes will have greater integrity and spatial relevance than fragmented (patchy) ones:

$$
S I I=\left(\frac{B s}{P n}\right) \times 0.01
$$

where SII is the Spatial Integrity Indicator, Bs is the biotope surface, and $P n$ is the number of patches of the biotope in each NPA.

For the seagrass meadows ecosystem, the spatial integrity was obtained from Equation (2), considering that seagrass meadows need a minimal size and density to maintain positive feedbacks for persistence [31]. The minimal area considered here is 5 ha, because a completely isolated patch in Akumal Bay has persisted for at least decades [32]:

$$
S I I_{s m}=\left[\% F P s-\left(\frac{\sum P S_{(<5 \mathrm{ha})}}{P n_{(<5 \mathrm{ha})}}\right)\right] \times 0.01
$$


where $S I I_{s m}$ is the Spatial Integrity Indicator for seagrass meadows, \%FPs (Equation (3)) is the percentage surface of functional patches ( $\geq 5 \mathrm{ha}$ ), Ps is the patch surface, $P n$ is the number of patches of the biotope, and Bs is the biotope surface in each NPA.

$$
\% F P s=\frac{\sum P s_{(\geq 5 h a)} \times 100}{B s}
$$

The Research Efforts Indicator is an estimate of the numbers of research/monitoring by ecosystems in both NPAs and Unprotected areas (Equation (4)). This indicator would shed light about the ecosystems less studied by areas (NPAs and Unprotected areas).

$$
R E I=\frac{S n \times S p}{B s}
$$

where REI is the Research Efforts Indicator, $S n$ is the number of studies compiled, by ecosystem, in every NPA, $S p$ is the study period (number of years of observation/monitoring by ecosystem in every NPA), and $B s$ is the surface area of the biotope in each NPA.

All analyses for determining the preservation of coastal ecosystems considered the government conservation priorities established for the region through the delimitation of Natural Protected Areas (NPAs) [3]. The delimitations of Priority Marine Regions (PMR) [4] were also reviewed (Table 1).

Table 1. Natural Protected Areas (NPAs) and Priority Marine Regions (PMRs) on the coast of the Mexican Caribbean.

\begin{tabular}{|c|c|c|c|}
\hline Official Names of the NPAs [3] & Management Category [3] & Abbreviations & PMR [4] \\
\hline Tiburón Ballena & Biosphere Reserve & TB & Extreme importance \\
\hline Yum Balam & Flora and Fauna Protection Area & YB & Extreme importance \\
\hline Playa de la Isla Contoy & Sanctuary & PC & \\
\hline Isla Contoy & National Park & IC & \\
\hline $\begin{array}{l}\text { Costa Occidental de Isla Mujeres, Punta } \\
\text { Cancún y Punta Nizuc }\end{array}$ & National Park & $\mathrm{CO}$ & \\
\hline Manglares de Nichupté & Flora and Fauna Protection Area & $\mathrm{MN}$ & \\
\hline Arrecife de Puerto Morelos & National Park & $\mathrm{APM}$ & \\
\hline $\begin{array}{l}\text { Porción norte y la franja costera oriental, } \\
\text { terrestres y marinas de la Isla de Cozumel }\end{array}$ & Flora and Fauna Protection Area & PN & Very important \\
\hline Arrecifes de Cozumel & National Park & $\mathrm{AC}$ & Very important \\
\hline Tulum & National Park & $\mathrm{TL}$ & Very important \\
\hline Arrecifes de Sian Ka'an & Biosphere Reserve & ASK & Extreme importance \\
\hline Sian Ka'an & Biosphere Reserve & SK & Extreme importance \\
\hline Banco Chinchorro & Biosphere Reserve & $\mathrm{BC}$ & Extreme importance \\
\hline Arrecifes de Xcalak & National Park & $\mathrm{AX}$ & Very important \\
\hline Caribe Mexicano & Biosphere Reserve & $\mathrm{CM}$ & \\
\hline Unprotected areas & & $\mathrm{U} / \mathrm{A}$ & \\
\hline
\end{tabular}
Ordered from North to South, as in the figures.

Note: Bahía de Akumal (Refuge for the protection of marine species) is also a NPA in the Caribbean Mexican but was not considered in this study due to the unavailability of shapefiles online.

\section{Coastline Evolution}

Coastline displacement (erosion and accretion in meters) over the last 45 years was obtained from data of Valderrama et al. [30], who digitized the coastlines in 1970/1980, 2005, 2010, and 2015. These authors interpreted coastline displacement as follows: (i) Continuous change: when the movements of the coastline, in the four time intervals digitized, showed the same direction; (ii) continuous gain: the coastline in the four time intervals showed accretion; (iii) continuous loss: the coastline in the four time intervals showed erosion; (iv) discontinuous change: when the movements of the coastline in the four time intervals showed different directions; and (v) no change: no displacement of the coastline. 
The average values of gain or loss in continuous or discontinuous changes were obtained considering all transects that presented these movements within a NPAs or Unprotected areas.

\subsection{Marine Climate}

\subsubsection{Waves}

Hourly data on variables of maritime climate from 1979 to 2019 were compiled for nine points along the coast of Quintana Roo. Significant wave height, peak period, wave direction, and wind speed and direction were obtained from the ERA5 climate reanalysis [33]. For each point, the mean value of the aforementioned variables was used of areas of $0.5^{\circ}$, between the latitudes $17.75^{\circ} \mathrm{N}$ and $21.75^{\circ} \mathrm{N}$.

The energy level of the waves and winds is presented as a function of the average power in the winter (November to April) and summer (May to October). The ranges of the power values were assigned according to the quartiles: higher than the third quartile-Very intense; between the third and second quartile-Intense; between the second and first quartile-Medium; and lower than the first quartile-Low (Table 2). In addition, for each latitude range, the average directions of the waves and winds corresponding to the seasons analysed were obtained. The directions are degrees true; relative to the geographic location of the North Pole [34].

Table 2. Wave and wind power ratings.

\begin{tabular}{ccc}
\hline Energy Level & Wave Power $(\mathbf{k W} / \mathbf{m})$ & Wind Power $\left(\mathbf{k W} / \mathbf{m}^{\mathbf{2}}\right)$ \\
\hline Low & $<5.3$ & $<0.21$ \\
Medium & $5.3<\mathrm{P}<5.9$ & $0.21<\mathrm{P}<0.24$ \\
Intense & $5.3<\mathrm{P}<6.5$ & $0.24<\mathrm{P}<0.26$ \\
Very intense & $>6.5$ & $>0.26$ \\
\hline
\end{tabular}

\subsubsection{Hurricanes}

Historical hurricane tracks (1851 to 2020) was obtained from NOAA-IBTrACS [35]. Time series analysis of frequency of the storms in each category of the Saffir-Simpson Hurricane Scale was calculated using Mann-Kendall's tests [36,37] and Sen's slope [38], taking into account the Yue and Wand autocorrelation method [39]. A mesh of 0.1 degree of resolution was created and the accumulated number of each Hurricane category for each spatial cell was mapped.

\subsection{Water Quality}

Water quality parameters were obtained from a bibliographic review for all the ecosystems described in Section 2.1. Concentrations of Dissolved Inorganic Nitrogen (DIN) and nitrogen stable isotopes $\left(\delta^{15} \mathrm{~N}\right)$ reported in different studies and the measurements of the CONAGUA water quality monitoring of 2018 were included [40].

Given the lack of specific criteria for tropical waters, the water quality values was classified according to the trophic status for waters of transition, coastal and marine areas proposed by EEA [41].

\subsection{Anthropization}

The degree of anthropization was assigned following the criteria of Cruz et al. [42], who classified stretches of coast (coastal compartments) as having high, moderate, low or no anthropization, according to human pressures: land use (combination of percentages of population, agriculture and/or natural), type of port (industrial, commercial or recreational), the presence or absence of anthropization on river banks, industry and artificial structures. The data used for this characterization is from 2017 to 2019. 


\section{Results}

From 1970 to 2020, we found 38 works published that examined the state or changes in the state of the ecosystems at 124 sites along the coast of the Mexican Caribbean (Figure 1 and Table S1). The total marine area was 6,383,700 hectares distributed in 12 NPAs, while the terrestrial part covered 473,390 ha in 14 NPAs. Most of the NPAs share marine and terrestrial area, only TB Biosphere Reserve is an only marine area, while MN, PC and TL National Park are only terrestrial.

\subsection{Coastal Ecosystems}

\subsubsection{Coral Reefs}

Coral reefs have a total surface of 10,536 ha in the Mexican Caribbean, of which $98.6 \%$ are within an NPA (10,389 ha). Cerdeira-Estrada et al. [27] does not show coral reefs in the NPAs of AC and BC; however, there is knowledge of the area of good development. The largest area of coral reefs is in the central part of the Mexican Caribbean (6307 ha, 60\%); the reefs' northern and southern regions comprise of $19 \%$ and $21 \%$ area coral reefs, respectively (Figure 2a).


Figure 2. Development and surface area of coral reef by region and for each NPA: (a) Development stages. (b) Coral reef surface and Research Efforts Indicator. (c) Coral reef surface and Spatial Integrity Indicator. The NPAs are listed from north to south, except for the Mexican Caribbean Biosphere Reserve (CM) and the Unprotected areas (U/A) are listed at last because they occur all along the coastline (See Table 1 for abbreviations).

Development of coral reefs in the Mexican Caribbean increases from North to South; with least developed reefs in the North and most developed (mature) reefs in the South (Figure 2a). In the articles reviewed, the degree of reef development was based on functional attributes (e.g., metabolic rates, biomass, development capacity) and community structure (e.g., species composition and cover, extension). The coral species determining reef structure in the northern region are Acropora palmata (e.g., Akumal, Puerto Morelos) 
and Porites astreoides (e.g., Cancun, Cozumel). The massive coral Orbicella sp. determines the structure, shape, and diversity in the species assemblage in the central and southern regions $[5,43]$.

Fifty-eight percent of the coral reef area is within extremely important PMRs, and $10 \%$ within very important PMRs, while $32 \%$ is in areas with no marine conservation priority. Most of the reef biotope research concentrates on the CO National Park, followed by the APM and the CM Biosphere Reserve (Figure 2b). It was not possible to calculate the research efforts in AC, as no reef patches were recorded by Cerdeira-Estrada et al. [27], even though 16 scientific articles have been written about the reefs there over the last 40 years.

The ASK coral reefs have the highest spatial integrity values, followed by YB. The lowest spatial integrity value was in AX and in Unprotected areas (Figure 2c).

\subsubsection{Seagrass Meadows}

Seagrass meadows cover 57,648 ha in the Mexican Caribbean, of which $92 \%$ is within the NPA (53,021 ha). The largest extensions (42,039 ha, 73\%) are in the north of the Mexican Caribbean. In the central area and in the south, most seagrass meadows are dominated by the climax seagrass Thalassia testudinum and sometimes Syringodium filiforme, although with lower density, as in AX and Boca Bacalar Chico [44,45]. Towards the north, T. testudinum is also present in most areas (Figure 3a); however, here shifts in relative dominance of fastergrowing pioneer species have been observed [20] (Figure 3a). However, above-mentioned studies are local, and region-wide mapping is necessary to discern (changes in) patterns at regional scale.

a)

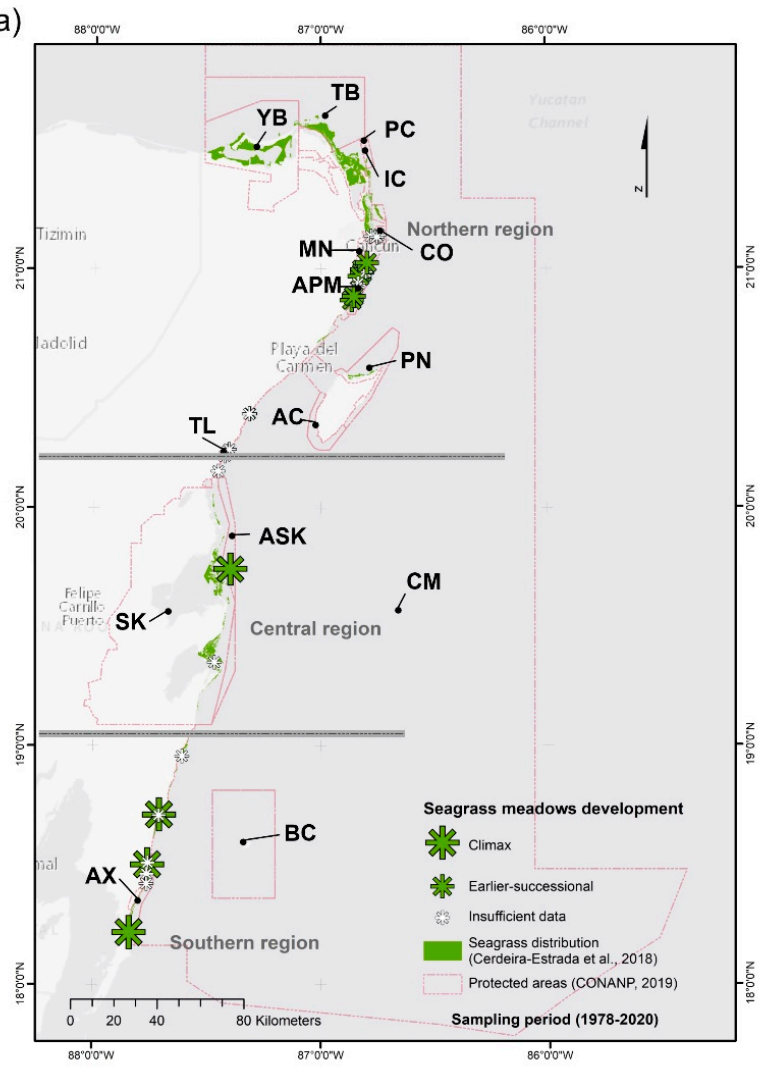

b)

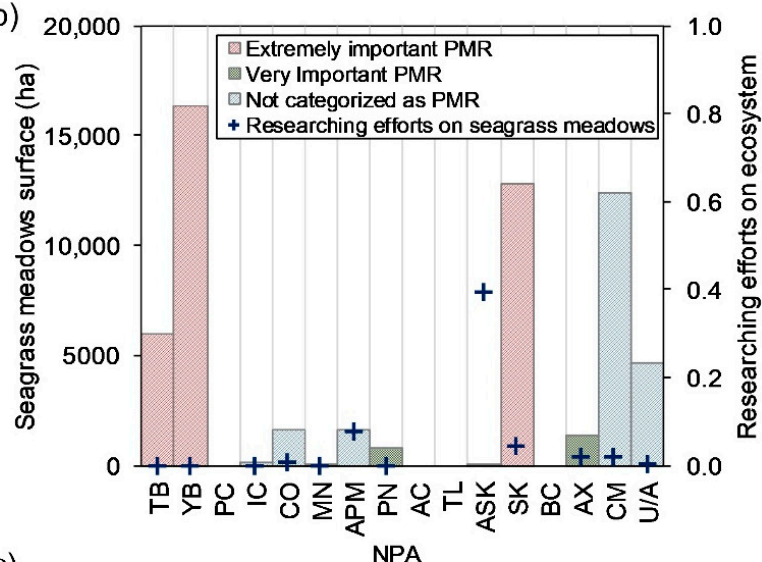

c)

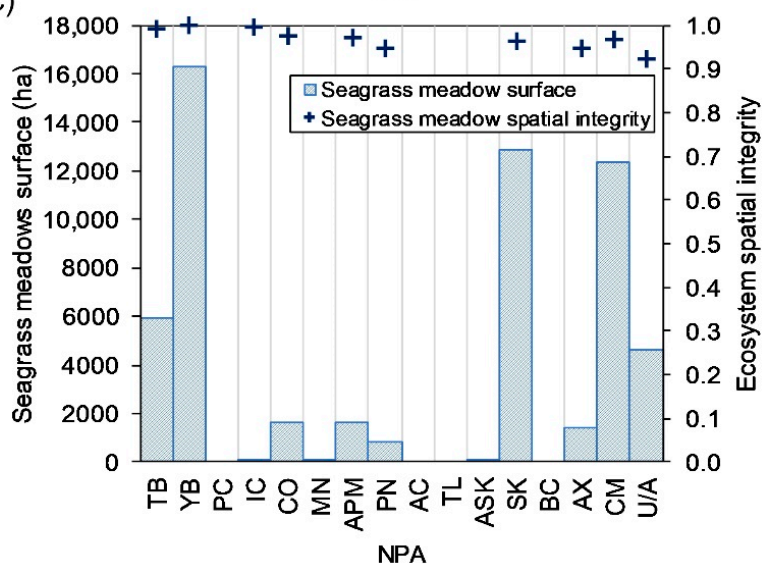

Figure 3. Development and surface area of seagrass meadows by region and for each NPA: (a) Development stages. (b) Surface of seagrass meadows and Research Efforts Indicator. (c) Spatial Integrity Indicator. The NPAs are listed from north to south, except for the Mexican Caribbean Biosphere Reserve (CM) and the Unprotected areas (U/A) are listed at last because they occur all along the coastline (See Table 1 for abbreviations). 
Sixty-one percent of the seagrass meadows in the region are within extremely important PMRs, and $2 \%$ within very important PMRs. The remaining meadows are in areas with no marine conservation priority, according to CONANP [4]. Most ecosystem research efforts concentrate on APM and ASK, although in other areas with larger surfaces (YB, SK and CM), there were also some studies (Figure 3b). Seagrass meadows in the Mexican Caribbean are not fragmented with high values of spatial integrity, the lowest value was recorded in Unprotected areas (Figure 3c).

\subsubsection{Mangrove}

There are 176,270 ha of mangroves in the Mexican Caribbean, of which $52 \%$ were in NPAs. The largest area of mangroves is in the central region (55\%), while the northern and southern regions comprise $14 \%$ and $31 \%$ of the total area, respectively. Disturbance is greatest in the north (1296 ha), where the area of mangroves is smallest, whereas in the central region only 5.6 ha was disturbed. In the southern region, $1 \%$ of the mangrove area was disturbed. 84,110 ha of mangroves ( $48 \%$ ) were found outside NPAs, and $1.5 \%$ of this area was perturbed (Figure 4a).

a)

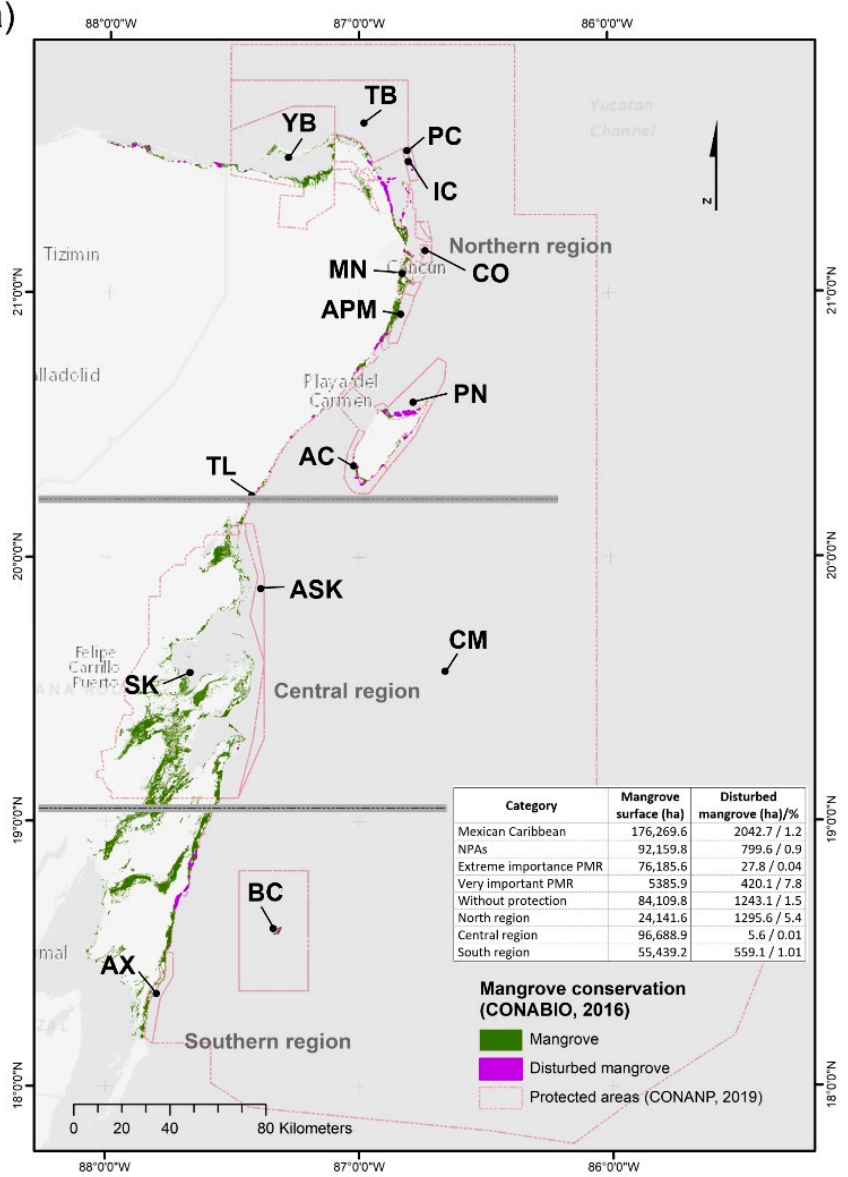

b)

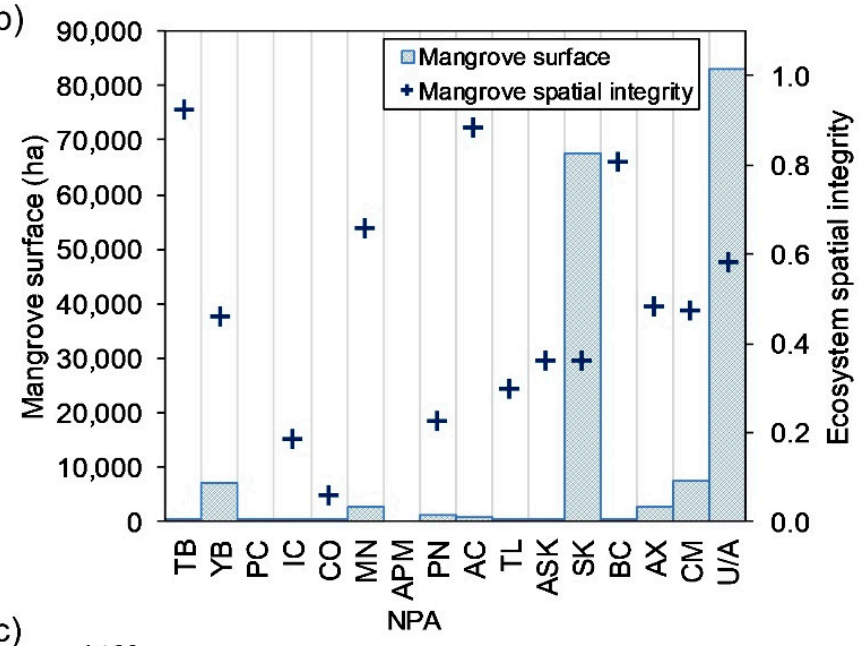

)

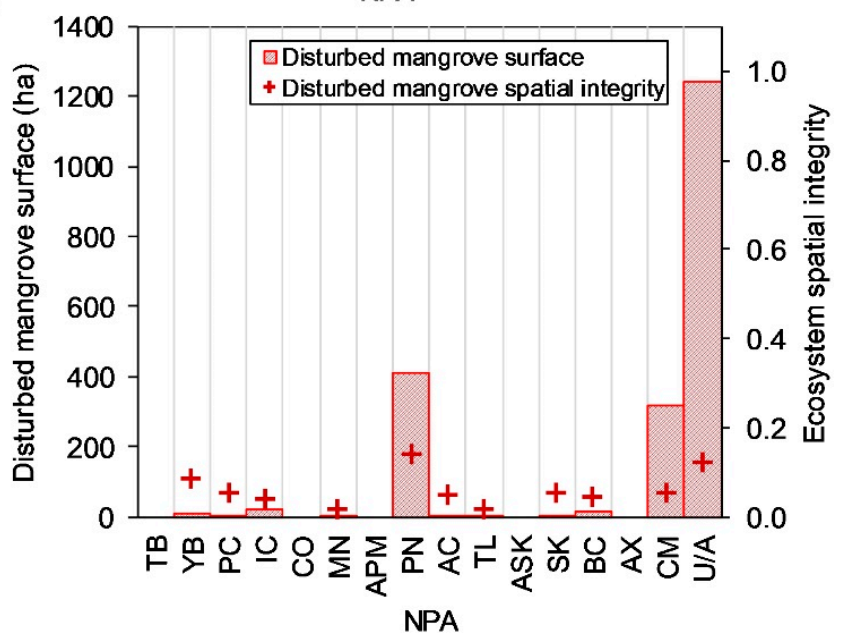

Figure 4. Conservation and mangroves area by region and for each NPA: (a) State of conservation. (b) Area of undisturbed mangrove and corresponding Spatial Integrity Indicator. (c) Area of disturbed mangrove and corresponding Spatial Integrity Indicator. The NPAs are listed from north to south, except for the Mexican Caribbean Biosphere Reserve (CM) and the Unprotected areas (U/A) are listed at last because they occur all along the coastline (See Table 1 for abbreviations).

Forty-three percent of the mangroves are in extremely important MPRs and 3\% in very important MPRs (Figure 4a). In general, little fragmentation is observed in the mangroves 
in good condition, with the lowest values in $\mathrm{CO}$ (Figure $4 \mathrm{~b}$ ). On the other hand, disturbed mangroves are highly fragmented, with SII values of less than 0.1 (Figure 4c).

\subsubsection{Coastal Dunes}

In the period 1995-2004, the Mexican Caribbean coast had 5353 ha of dunes, and this area was 5128 ha in 2015-2020, showing a 225 ha total loss in the dune ecosystems. The greatest coastal dune areas were in the north $(91 \%)$, where the decrease in dune extension was also largest (169 ha). In the central region, the extension of dunes was only $6 \%$, with a loss of 24 ha, while in the southern region the dune extension was 3\%, with losses of 32 ha (Figure 5a).

a)

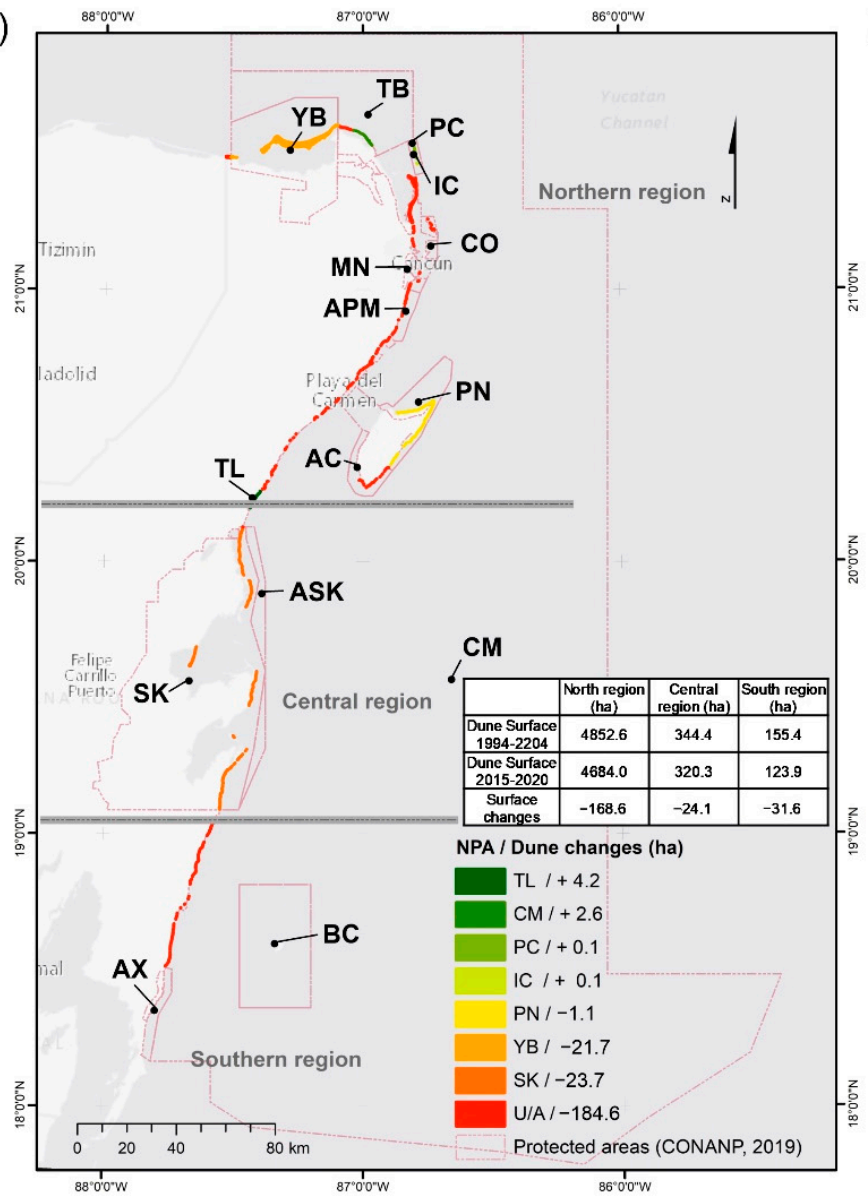

b)

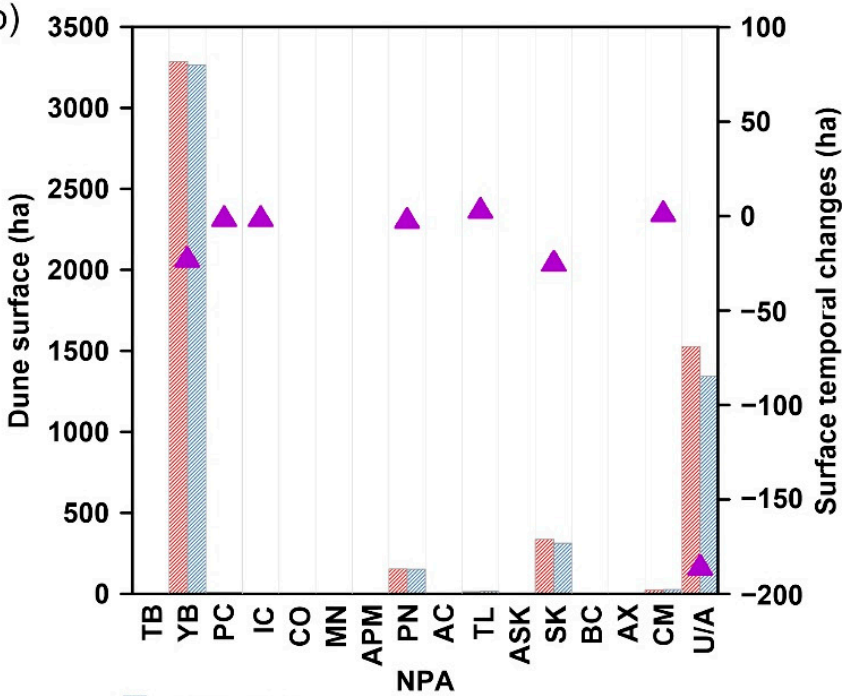

$2015-2020$

$1995-2004$

A $1995-2004 / 2015-2020$

\begin{tabular}{|c|r|r|r|}
\hline NPA & $\begin{array}{c}\text { Dune surface } \\
\text { 1995-2004 (ha) }\end{array}$ & $\begin{array}{c}\text { Dune Surface } \\
2015-2020 \text { (ha) }\end{array}$ & $\begin{array}{c}\text { Surface } \\
\text { changes (ha) }\end{array}$ \\
\hline YB & 3286.7 & 3265 & -21.7 \\
\hline PC & 10.7 & 110.8 & 0.1 \\
\hline IC & 0.8 & 0.9 & 0.1 \\
\hline PN & 153.3 & 152.3 & -1.1 \\
\hline TL & 12.7 & 16.9 & 4.2 \\
\hline SK & 336.6 & 312.9 & -23.7 \\
\hline CM & 24.5 & 27 & 2.6 \\
\hline U/A & 1527.0 & 1342.4 & -184.6 \\
\hline
\end{tabular}

Figure 5. Changes in dune extension (ha) for the periods 1996-2004 and 2015-2020. (a) By region. (b) By NPA, and in the Unprotected areas. The NPAs are listed from north to south, except for the Mexican Caribbean Biosphere Reserve (CM) and the Unprotected areas (U/A) are listed at last because they occur all along the coastline (See Table 1 for abbreviations).

Approximately $72 \%$ of the dune area is in NPAs; 3825 ha in 1995-2004 and 3786 ha in 2015-2020. The barrier island of Holbox, in YB, had the greatest extension (3287 and 3265 ha for 1995-2004 and 2015-2020, respectively), followed by parts of the Unprotected areas (1527 and 1342 ha). Otherwise, IC had the lowest dune surface (1 ha in both periods) (Figure 5b).

The greatest loss in dune areas (185 ha) occurred in the Unprotected areas. In summary, in the Unprotected Areas, $\mathrm{SK}, \mathrm{YB}$, and $\mathrm{PN}$, there was a decrease in dune surface in the most recent period; while in $\mathrm{CM}, \mathrm{TL}, \mathrm{IC}$, and $\mathrm{PC}$, the dune surface increased between 0.1 and 4.2 ha (Figure $5 b)$. 


\subsubsection{Coastline}

The northern region had discontinuous changes on $56 \%$ of its coastline, while that of the rest showed no changes. This was the only one that had continuous losses and gains in a minimum part of its coastline $(0.2 \%)$. In the central region, the discontinuous changes were $25 \%$ and without changes of $43 \%$. Finally, the greatest discontinuous changes were in the southern (57\%), while was 7\% without changes (Figure 6a).

a)



b)

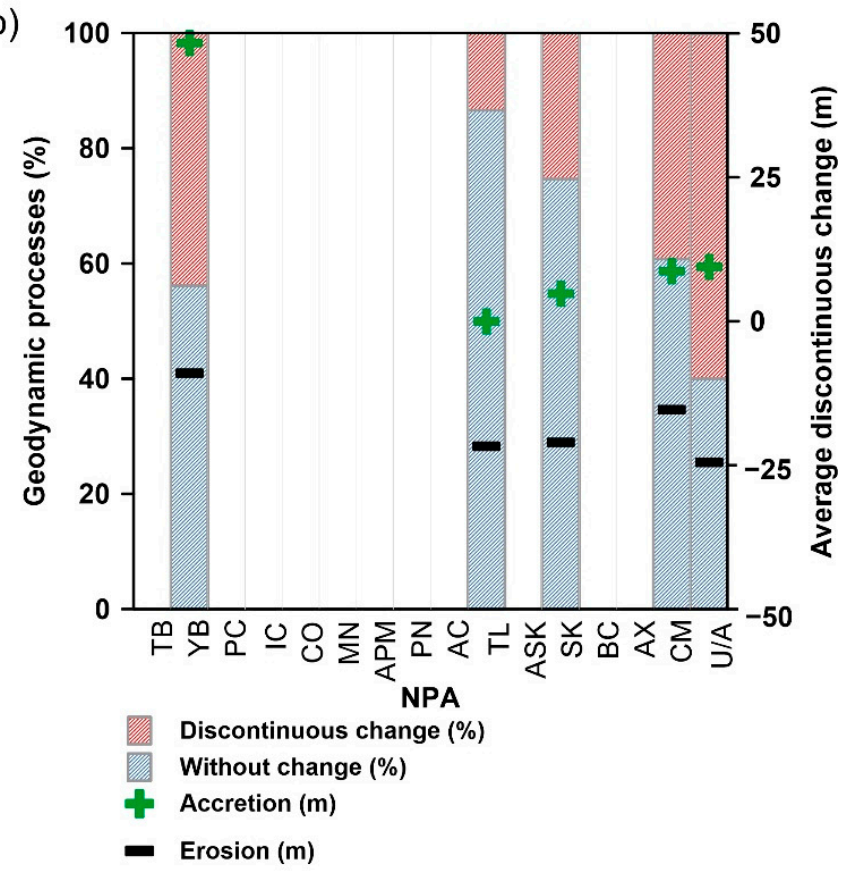

\begin{tabular}{|c|c|c|c|c|}
\hline NPA & $\begin{array}{c}\text { Average } \\
\text { discotinuous } \\
\text { gain }(\mathrm{m})\end{array}$ & $\begin{array}{c}\text { Average } \\
\text { discotinuous } \\
\text { loss }(\mathrm{m})\end{array}$ & $\begin{array}{c}\text { Average } \\
\text { cotinuous } \\
\text { gain }(\mathrm{m})\end{array}$ & $\begin{array}{c}\text { Average } \\
\text { cotinuous } \\
\text { loss }(\mathrm{m})\end{array}$ \\
\hline YB & 48.3 & 9.0 & 0.0 & 0.0 \\
\hline TL & 0.0 & 21.7 & 0.0 & 0.0 \\
\hline SK & 4.8 & 21.0 & 0.0 & 0.0 \\
\hline CM & 8.7 & 15.4 & 0.0 & 0.0 \\
\hline U/A & 9.4 & 24.5 & 69.8 & 60.7 \\
\hline
\end{tabular}

Figure 6. Geodynamics in Quintana Roo. (a) By region. (b) Erosion/Accretion percentage change for each NPA and the Unprotected areas. The NPAs are listed from north to south, except for the Mexican Caribbean Biosphere Reserve (CM) and the Unprotected areas (U/A) are listed at last because they occur all along the coastline (See Table 1 for abbreviations).

The Unprotected areas had the highest percentage of discontinuous change in the study period ( $60 \%$ of its coastline), with average gains of $9.4 \mathrm{~m}$ and average losses of $24.5 \mathrm{~m}$. Regarding continuous changes, an average gain of $69.8 \mathrm{~m}$ and average loss $60.7 \mathrm{~m}$ were recorded. SK had discontinuous change with average accretion of $4.8 \mathrm{~m}$, and erosion of $21 \mathrm{~m}$. In YB, discontinuous change was found in $44 \%$ of the coastline, with an average accretion of $48.3 \mathrm{~m}$ and $9 \mathrm{~m}$ of erosion. In TL, 13\% of the coastline showed discontinuous change, with an average erosion of $21.7 \mathrm{~m}$. In CM, discontinuous change of $8.7 \mathrm{~m}$ on average was found for accretion and $15.4 \mathrm{~m}$ for erosion (Figure $6 \mathrm{~b}$ ).

\subsection{Stressors}

\subsubsection{Wave and Wind Climate}

The intensities of wave and wind power decrease from north to south for the period from November to April, although in the southern part of the central region $\left(19.25^{\circ}\right.$ to $19.75^{\circ} \mathrm{N}$ ) both wave and winds were also very intense (Table 3). From May to October, the 
strongest wind power was over the central region, although there was no direct correlation with wave power (Table 4).

Table 3. Wave and wind power in the Mexican Caribbean in winter (November to April).

\begin{tabular}{|c|c|c|c|c|c|c|}
\hline Region & $\begin{array}{c}\text { Minimum } \\
\text { Latitude }\end{array}$ & $\begin{array}{c}\text { Maximum } \\
\text { Latitude }\end{array}$ & $\begin{array}{c}\text { Wave Power } \\
(\mathrm{kW} / \mathrm{m})\end{array}$ & $\begin{array}{l}\text { Mean Wave } \\
\text { Direction }\left({ }^{\circ}\right)\end{array}$ & $\begin{array}{c}\text { Wind Power } \\
\left(\mathrm{kW} / \mathrm{m}^{2}\right)\end{array}$ & $\begin{array}{l}\text { Mean Wind } \\
\text { Direction }\left({ }^{\circ}\right)\end{array}$ \\
\hline \multirow{4}{*}{ North } & 21.75 & 22.25 & Intense & 42 & Medium & 77 \\
\hline & 21.25 & 21.75 & Very intense & 62 & Very intense & 80 \\
\hline & 20.75 & 21.25 & Very intense & 74 & Very intense & 78 \\
\hline & 20.25 & 20.75 & Low & 99 & Low & 80 \\
\hline \multirow[t]{3}{*}{ Central } & 19.75 & 20.25 & Medium & 91 & Intense & 74 \\
\hline & 19.25 & 19.75 & Very intense & 83 & Very intense & 75 \\
\hline & 18.75 & 19.25 & Low & 86 & Low & 76 \\
\hline \multirow[t]{2}{*}{ South } & 18.25 & 18.75 & Low & 84 & Low & 74 \\
\hline & 17.75 & 18.25 & Intense & 80 & Intense & 73 \\
\hline
\end{tabular}

Table 4. Wave and wind power in the Mexican Caribbean in summer (May to October).

\begin{tabular}{|c|c|c|c|c|c|c|}
\hline Region & $\begin{array}{l}\text { Minimum } \\
\text { Latitude }\end{array}$ & $\begin{array}{l}\text { Maximum } \\
\text { Latitude }\end{array}$ & $\begin{array}{c}\text { Wave Power } \\
(\mathrm{kW} / \mathrm{m})\end{array}$ & $\begin{array}{l}\text { Mean Wave } \\
\text { Direction }\left(^{\circ}\right)\end{array}$ & $\begin{array}{c}\text { Wind Power } \\
\left(\mathrm{kW} / \mathrm{m}^{2}\right)\end{array}$ & $\begin{array}{l}\text { Mean Wind } \\
\text { Direction }\left(^{\circ}\right)\end{array}$ \\
\hline \multirow{4}{*}{ North } & 21.75 & 22.25 & Low & 85 & Low & 95 \\
\hline & 21.25 & 21.75 & Intense & 100 & Intense & 98 \\
\hline & 20.75 & 21.25 & Very intense & 103 & Intense & 99 \\
\hline & 20.25 & 20.75 & Low & 116 & Low & 104 \\
\hline \multirow{2}{*}{ Central } & 19.75 & 20.25 & Intense & 107 & Very intense & 96 \\
\hline & 19.25 & 19.75 & Very intense & 102 & Very intense & 97 \\
\hline \multirow{3}{*}{ South } & 18.75 & 19.25 & Medium & 100 & Low & 96 \\
\hline & 18.25 & 18.75 & Medium & 99 & Intense & 94 \\
\hline & 17.75 & 18.25 & Very intense & 95 & Very intense & 93 \\
\hline
\end{tabular}

In the period analysed from 1851 to 2020, 1287 extreme weather events were recorded in the Mexican Caribbean, from tropical depressions (TD) to hurricanes of maximum intensity on the SSHS (Saffir-Simpson Hurricane Scale). The Mexican Caribbean saw 525 TD in this period and, at the other end of the scale, 13 hurricanes of category 5 (H5).

In this period, 440 Tropical Storms (TS), 132 Category 1 hurricanes (H1), 93 Category 2 hurricanes (H2), 41 Category 3 hurricanes (H3), and 43 Category 4 hurricanes (H4) passed over the Mexican Caribbean.

The most active period was from 1886 to 1979 , with additional peaks in frequency of TD in the years 1854, 1887, and 1970 (Figure 7a). There were no minor hurricanes (H1 \& H2) from 1967 to 1995 and from 2012 to 2019 (Figure 7b).

High category hurricanes (H3 and higher) started to affect the Mexican Caribbean in 1896 (H3), in 1915 (H4) and 1955 (H5). Only 13 H5 hurricanes were recorded over the 170 years analysed, all within a 52-year interval (1955 to 2007) but showing no trend of statistical significance. H3 hurricanes showed no trend of statistical significance, although there was an increasing trend in $\mathrm{H} 4$ hurricanes passing through the Mexican Caribbean ( $p$-value $<0.005$ and Sen's slope of 0.062). There was no clear trend for other category hurricanes, although the sum of $\mathrm{H} 4$ and $\mathrm{H} 5$ passing through the area did show an increase, with a $p$-value of 0.030 and a Sen slope of 0.036 (Table 5 and Figure 8). 
a)

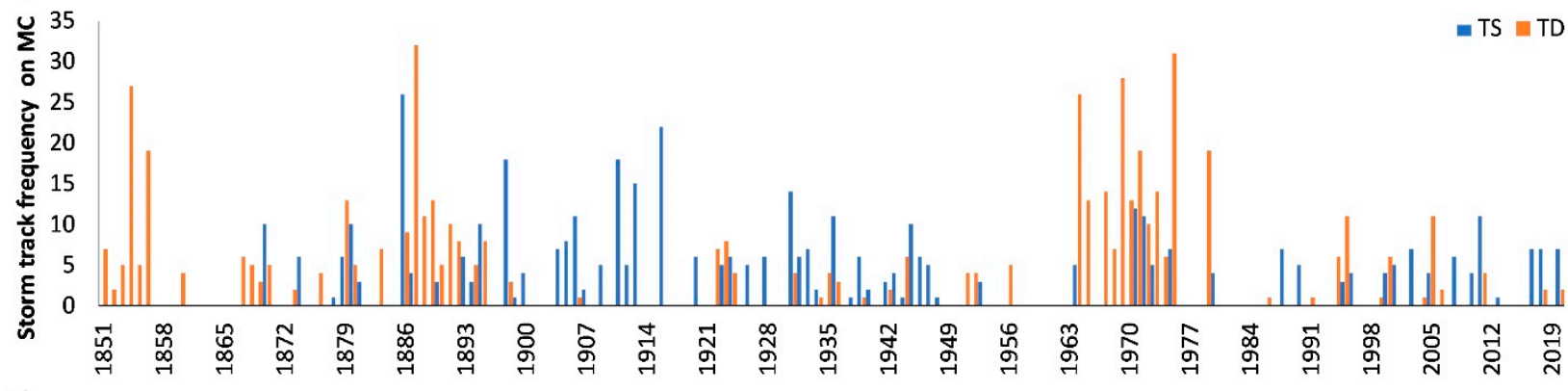

b)

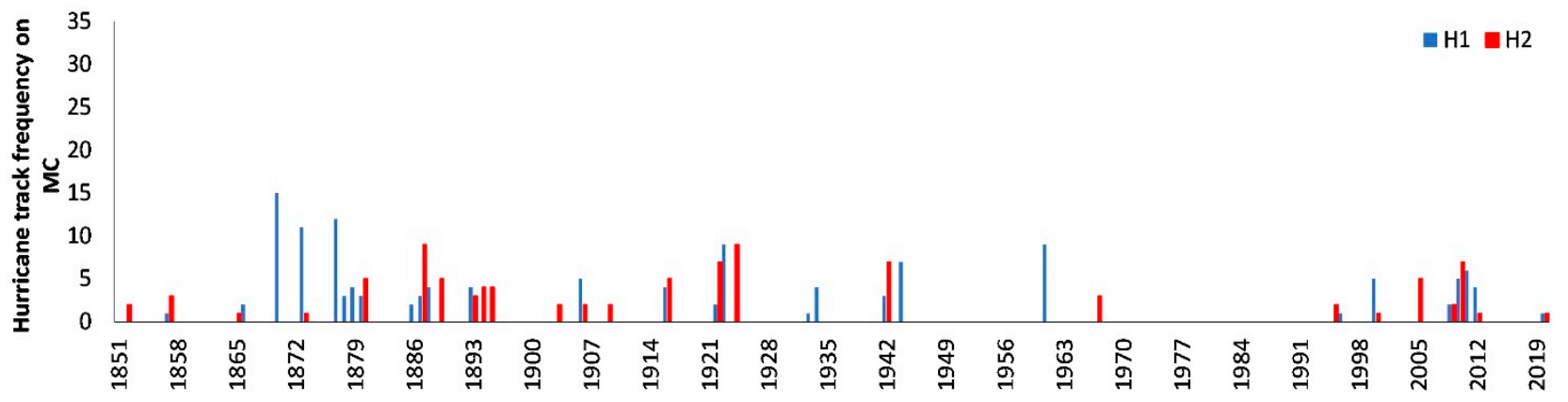

Figure 7. Frequency of extreme meteorological events passing through the Mexican Caribbean, 1851-2020: (a) Tropical Depressions and Tropical Storms; (b) Hurricanes of categories H1 and H2.

Table 5. Estimation of trends of hurricane track frequency, 1851 to 2020, in the Mexican Caribbean (Mann-Kendall test and Sen's slope estimator test).

\begin{tabular}{ccccc}
\hline Saffir-Simpson Scale & Mann-K tau $(\tau)$ & $p$-Value & Sen's Slope & Trend Estimation \\
\hline TD & 0.033 & 0.762 & 0.000 & No trend \\
TS & -0.090 & 0.323 & 0.000 & No trend \\
H1 & -0.079 & 0.285 & 0.000 & No trend \\
H2 & -0.187 & 0.150 & -0.009 & No trend \\
H3 & 0.179 & 0.216 & 0.012 & No trend \\
H4 & 0.509 & 0.046 & 0.062 & Trend \\
H5 & 0.105 & 1.000 & 0.011 & No trend \\
H4 + H5 & 0.357 & 0.044 & 0.023 & Trend \\
\hline
\end{tabular}



Figure 8. High intensity hurricanes in the Mexican Caribbean, 1851-2020.

The entire region was equally affected by the passage tropical storms and minor hurricanes (H1 and H2) (Figure 9a-c). Major hurricanes (H3-H5) passed more frequently over the northern region (Figure $9 \mathrm{~d}-\mathrm{f}$ ). 

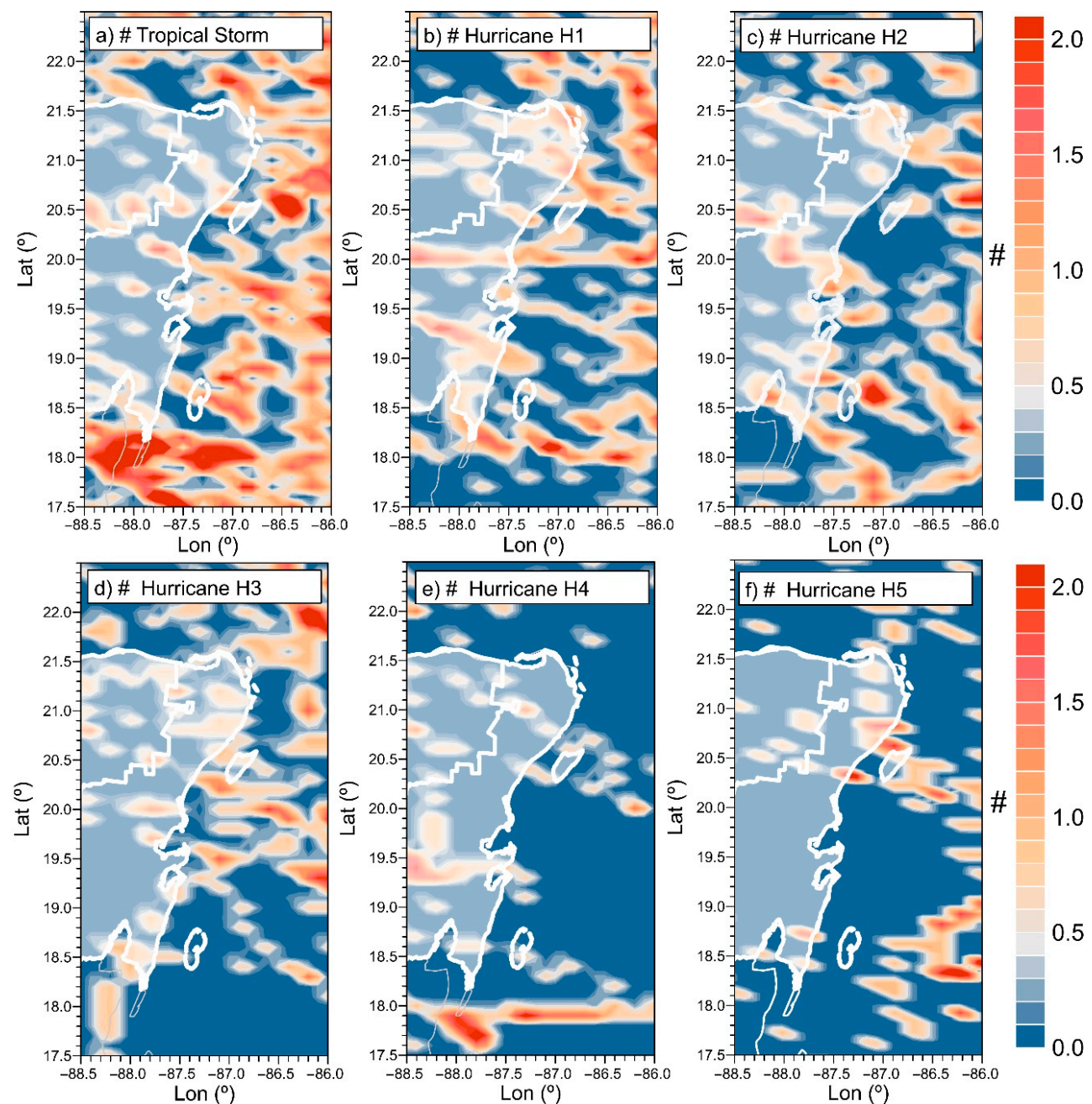

Figure 9. Density of Tropical storms and hurricanes over the Mexican Caribbean, 1851-2020.

\subsubsection{Water Quality}

The DIN concentrations of 124 sites on the coast of the Mexican Caribbean were analysed. At the sites classified as oligotrophic, DIN values ranged from $0.86 \mu \mathrm{M}$ to $6.42 \mu \mathrm{M}$. These were recorded in the protected areas of YB, CO, APM, AC, SK, BC, and AX at several sites in the CM Biosphere Reserve, and in Unprotected Areas (Figure 10).

Mesotrophic and eutrophic sites with DIN of 6.71-110.48 $\mu \mathrm{M}$ were recorded mostly in the northern region, with the highest DIN concentration in the study area $(110.48 \mu \mathrm{M})$ in $\mathrm{CM}$ (Playa del Carmen). Other isolated records with medium to high DIN in central and southern regions were recorded in the CM (Shambala, Chávez, Mahahual), SK, and AX (Figure 10).

Studies reporting nitrogen isotopic signature are more common in the north (Figure 10), with $>10 \% \delta^{15} \mathrm{~N}$ in tissues of seagrasses in Laguna de Nichupté $[46,47]$. In the central region, the $\delta^{15} \mathrm{~N}$ ranged from $4.9-6.7 \%$ and in the southern region from $0.2-7 \%$ $\delta^{15} \mathrm{~N}$ [46-49]. The highest number of sites with eutrophic conditions were found in CM $(75 \%)$, of which $67 \%$ occurred in the northern region, followed by SK and an unprotected site (Laguna Nichupté).

\subsubsection{Anthropization}

The northern region had the highest percentages of high and moderate anthropization (Figure 11a), concentrated especially in the tourist zones of Holbox, Cancun, Isla Mujeres, and Playa del Carmen, followed by moderate anthropization in Cozumel. In the central region, anthropization is lower (13\%) because of its extensive and widespread wetland 
areas, unsuitable for urbanization. In the southern region, low (3\%) to moderate $(7 \%)$ anthropization were recorded (Figure 11a).

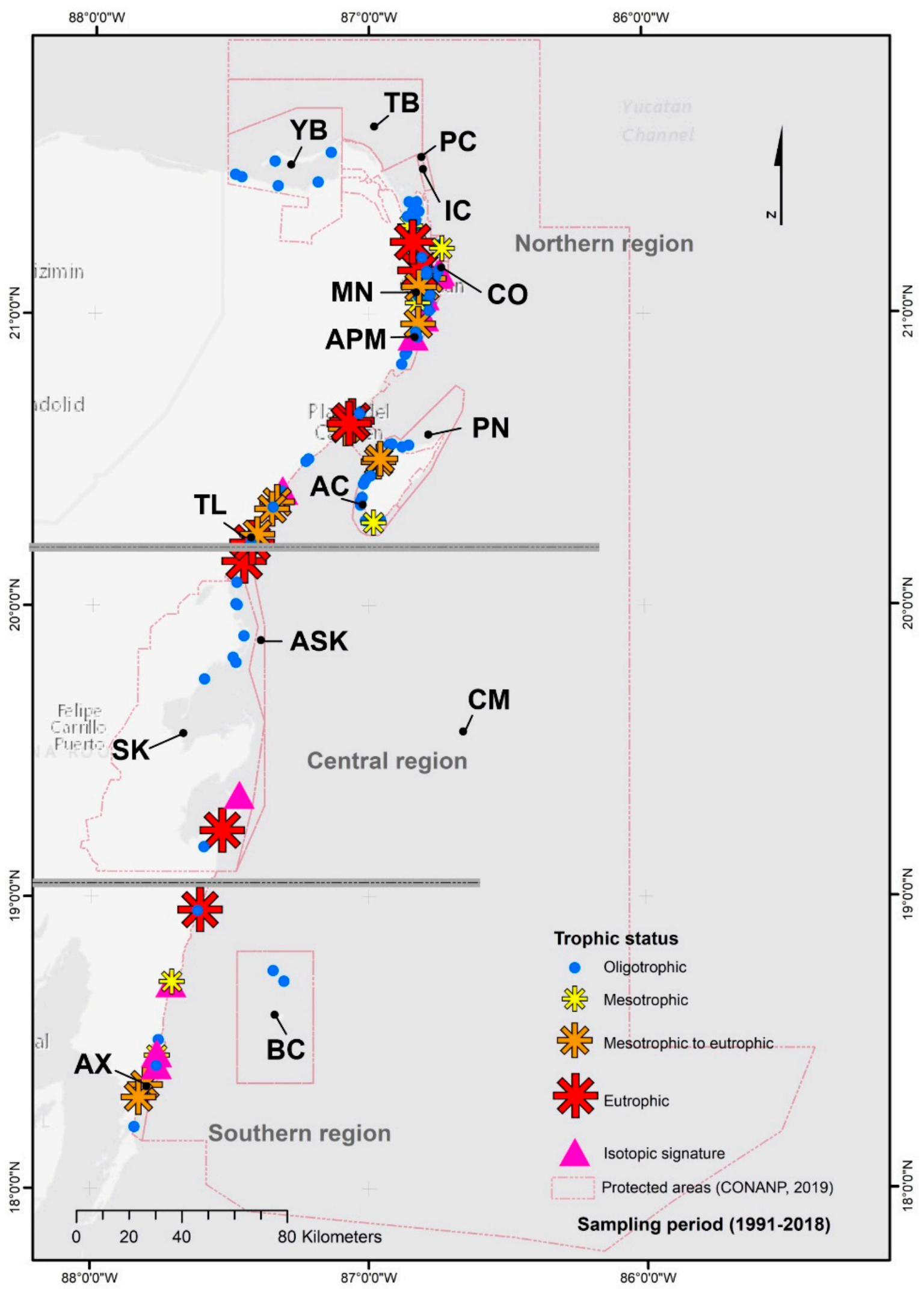

Figure 10. Water quality along the coast of the Mexican Caribbean (See Table 1 for abbreviations). 
a)

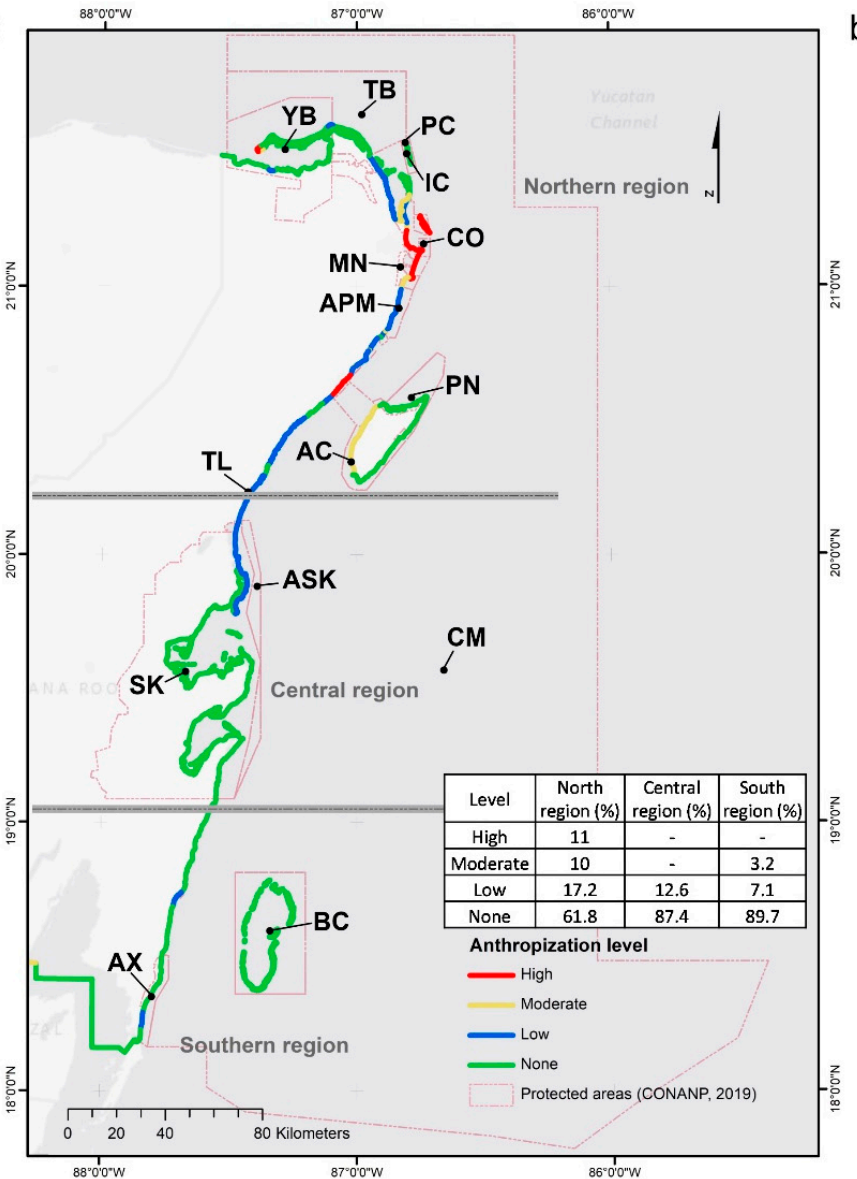

b)

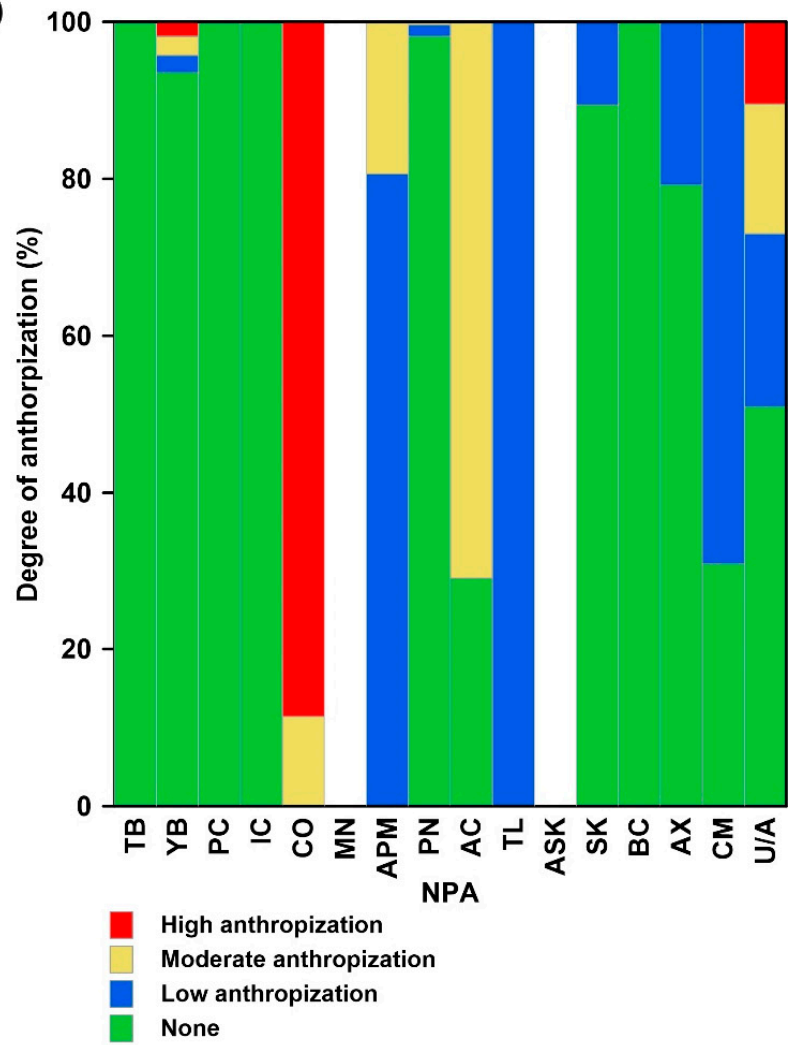

Figure 11. Degree of anthropization in Quintana Roo (modified from Cruz et al., 2019). (a) By regions. (b) For each NPA and for the Unprotected areas. The NPAs are listed from north to south, except for the Mexican Caribbean Biosphere Reserve (CM), and the Unprotected areas (U/A) are listed at last because they occur all along the coastline (See Table 1 for abbreviations).

In the NPAs, only $2 \%$ of the coast had high anthropization, recorded in Cancun and Holbox (CO and $\mathrm{YB})$, while moderate anthropization $(4 \%)$ was recorded in AC, APM, and $\mathrm{CO}$ (Figure 11). 1.4\% of the PN had low anthropization with small populations in some stretches of coast; while in $\mathrm{TL}$, the entire coast had low anthropization. In addition, there was low anthropization (11\%) on the coast of SK and no anthropization elsewhere. In the case of CM, anthropization was low. IC and PC show no coastal anthropization. On the other hand, the unprotected coastal areas had the highest percentages of high anthropization (10\%) (Figure 11b).

\section{Discussion}

Preservation state of the coastal ecosystems in the Mexican Caribbean increased from north to south, which is related to the degree of anthropization mainly due to urban and tourist developments. However, Argüelles-Jiménez et al. [28] attributed the increasing north-south gradient in structure and development of coral reefs along the coast mainly to the geomorphological setting and the topology; thus, the north-south gradient in reef development may also be attributed to natural settings. However, this gradient in preservation state over the last decades is also present in the other ecosystems covered in this study, and the response variables to anthropization were sufficiently robust across the studied ecosystems. In the following discussion, we will focus on how the coastal ecosystems are affected by physical-chemical stressors. 


\subsection{Coastal Ecosystems and Wave Climate}

The northern part of the region has the waves and extreme events of highest energy; southwards this energy decreases. This is reflected in the ecosystems, mainly the coral reefs, where species found there are more resistant to extreme events, and the hydrodynamics produce higher levels of oxygenation. It is possible that the coral reef species in this area are more resilient to future changes in the intensity of extreme events. Coral reefs have been found to be more resilient to rising wave heights than to sea level rise [50].

The higher wave energy in the north, together with the lesser "maturity" of the reefs, may have induced higher erosion damage in the beach dune systems $[13,50,51]$. Moderately high energy regimes do not affect well-developed seagrass meadows in reef lagoons. Seagrass meadows dominated by the robust climax species Thalassia testudinum resist major hurricanes [21,52]. However, if the seagrass meadows start fragmenting [53,54] or undergo shift in specific composition, towards earlier successional species with lower rooting capacity [55] due to anthropization (eutrophication or other disturbance), high energy regimes or events may affect the meadows and, thereby, the stability of adjacent beaches [56].

The Yucatan current is crucial in spreading larvae and nutrients in the marine ecosystems studied (seagrasses and coral reefs) [57]. The Yucatan current flows northward through the Mexican Caribbean Sea and connects the ecosystems unidirectionally (from the south, through the central area and to the north). The velocity of the current is greater in the central-northern sector $(0.5 \mathrm{~m} / \mathrm{s})$, than in the southern-central sector $(0.2 \mathrm{~m} / \mathrm{s})$ [58]. However, nearshore counter currents allow for propagule transport both north and southwards, indicated by genetically well mixed populations of seagrasses and corals along the Mexican Caribbean coast [59,60].

\subsection{Coastal Ecosystems and Water Quality}

Mexican Caribbean ecosystems used to be oligotrophic, providing optimal environment for the development of coral reef systems; eutrophication indicated by higher DIN records in the north, is therefore a threat. Ecosystem changes associated at some site in the northern region coincide with other high DIN records [61,62]. Coastal development of Cancun hotel zone around APM National Park and Nichupté Lagoon System has been a source for nutrients for several decades $[46,63,64]$. The absence of a sewage system in many places, such as Puerto Morelos, the porous karstic geology, and the underwater springs typical of the region produce a system that is susceptible to significant nutrient inputs from land-based sources [65-67]. The recent increasing nutrient inputs in the more southern areas of the Mexican Caribbean [46-49] should be a warning for local coastal managers, due to the better state of the ecosystems in this region, which could be affected in the long term if the discharges increase.

Most records of water quality in the northern region could be related to the high level of anthropization there. A similar situation could be possible for the central and southern regions in the medium and long term, due to the increase of sites with advanced trophic status and recent records of wastewater inputs. Therefore, special attention should be paid to water quality management in the NPAs throughout the region. High nutrient concentrations can stimulate macroalgae growth [68,69], especially in the absence of adequate herbivory intensity [70,71], affecting the resilience of coral ecosystems. In particular, landbased activities and marine eutrophication resulting from inadequate wastewater treatment is considered a principal driver of declining reef condition in the Mexican Caribbean [72]. Similarly, elevated nitrogen records, such as in the northern and southern regions, stimulate excessive growth of epiphytes on the leaves of marine angiosperms [73-77], which eventually leads to ecosystem deterioration. This, in turn, causes a decline in their resilience in the face of storms, and in extreme cases to the loss of the seagrass meadows [73]. 


\subsection{Coastal Ecosystems and Anthropization}

The continuous retreat of the coastline in the northern region (2-3 m per year) coincides with its high degree of anthropization, and corresponds with reports on erosion rates of 0.25 and $9 \mathrm{~m} \mathrm{y}^{-1}$ for $70 \%$ of the beaches in the Caribbean [2]. This region is the least developed coral reefs, which coincides with Suchley and Alvarez-Filip [78], who found that the coral cover was significantly lower in sites with high local human activity. The modification of the coastline by anthropization, combined with high wave and wind energies affecting hydrodynamics and dissipation of wave energy by the dune-beach system, impacts the coastal sediment transport [79,80]. Coastal development can lead to elevated sediment and nutrient run-off [81]. Sedimentation raises water turbidity, reducing coral photosynthetic activity, energy reserves and growth, and has been linked with elevated coral disease prevalence [82]. Additionally, excessive sedimentation can cause fragmentation of seagrass meadows [83-85] having major implications for both biological productivity and ecosystem connectivity.

Mangroves are also most disturbed in the northern region, which can generally be attributed to deforestation [86]. In the southern region, the second-most disturbed of the study area, Hirales-Cota et al. [22] identified anthropogenic land use (e.g., construction of villages and roads) as the main cause of disturbance in mangrove areas.

The dunes in the northern region have been impacted by the high anthropization and major discontinuous changes in the coastline, causing the loss of dune area, specifically in Unprotected areas. Tourist developments, e.g., hotel buildings, roads, and golf courses, have destroyed the dunes in these areas. In the satellite images it was observed that the main changes in the polygons were due to the construction of infrastructure. Martínez et al. [25] highlight that some hotels have implemented artificial reefs and geotextiles to reduce the erosion of the beach-dune. Others have opted for the construction of groins to protect the beach, interrupting the littoral transport, and causing erosion on nearby beaches.

In the central and southern regions with less anthropization, changes in the dune area are not as pronounced as in the north. Changes to dune area in the south have been caused by the construction of the coastal roads and isolated human settlements, which have fragmented the frontal dunes [25]. On the other hand, sediments move principally southwards, feeding the beaches. Additionally, the nearby reefs provide a supply of sediments and protection to the shoreline near to them [87].

\subsection{Coastal Ecosystems and NPAs}

Forty-nine percent of the coral reef ecosystems in the Mexican Caribbean are in SK and represent $72 \%$ of the PMRs. Although coral reefs in AC and BC are not mapped by Cerdeira-Estrada et al. [27], these parks have well-developed and mature reefs $[43,61,88,89]$ and should be included in future studies. There is no direct relationship between research efforts values and the biotope surface in NPAs. In fact, there is less research on NPAs with extensive ecosystem than areas with less coral reefs, which is perhaps due to the proximity to research centers. The coral reefs have low spatial integrity values (many patches), except in YB and ASK. A loss of reef structure complexity has been reported in the Mexican Caribbean over the last 40 years [90]. In addition, the structure of the corals in the region has been severely affected recently due to the disease known as stony coral tissue loss [91].

The largest protected areas of seagrasses are in $\mathrm{YB}$ and SK, together accounting for $51 \%$ of the total area. The seagrass meadows in the northern region, specifically APM and $\mathrm{CO}$, have no marine conservation priority [4] and are also those most affected by natural and anthropic disturbances. The fact that ASK has the highest value in the REI is due to the small area of the ecosystem ( $2.5 \mathrm{ha})$; this value should be analysed cautiously. As with coral reefs, there is no direct relation between research undertaken and the biotope surface in NPAs, which allowed identification of zones with a lack of information about ecosystems conservation status.

Of all the coastal ecosystems, seagrass meadows have received least attention. The absence of any high-resolution monitoring program that details surface area and evaluates 
specific composition is urgently needed to establish a baseline for future work. The relative abundance of climax vs. fast-colonizing species is a useful indicator of preservation state [29]. However, the works reviewed on seagrasses cover very small areas, or only sampling points, of the vast meadows, and do not provide the necessary spatial information to assess the state of entire meadows. There are various fragmentation indices for seagrass meadows $[53,91]$. The spatial integration index suggested in this paper can easily be obtained from GIS data, and is easy to use. It is based on the locally observed, minimal size of a functional completely isolated Thalassia testudinum meadow. Fragmentation in seagrasses affects their resilience, leading to a decrease in resistance and recovery from disturbances [92]. The low fragmentation in the seagrass meadows of Mexican Caribbean is a result of topography and widely available sandy substrate in reef and coastal lagoons for seagrass development $[93,94]$. Major disturbances, such as extreme eutrophication or siltation (e.g., Bojórquez Lagoon in MN), sargassum brown tides [16], excessive turtle grazing [32], and hurricanes [21] have locally eradicated seagrass meadows; thus, meadow fragmentation can be become an issue, when (changed) local conditions do not allow for recovery. Therefore, spatial integrity together with possible changes in specific composition should both be included in future monitoring programs.

Mangroves in the north, especially around Cancun, are those most severely affected by anthropization, which began at the beginning of the 1980s [23,95]. Other areas; e.g., PN has reported a loss of $24 \%$ and a gain of $7 \%$, while most of the coverage $(69 \%)$ showed no change [96], and was described as well conserved. However, in 2016, CONABIO identified for the same protected area (PN) 33\% of mangrove areas as "disturbed", representing the greatest damage of all NPAs. The disturbed mangrove in the southern region, specifically in Mahahual-Xcalak, had an annual deforestation rate of $0.85 \%$, which is high compared to other mangrove forests in Mexico [22]. However, Cinco-Castro and Herrera-Silveira [97] found that mangroves in the south (Mahahual) are most vulnerable to Global Climate Change of all the mangroves along the coast of the Yucatan peninsula.

The coastal dunes within the NPAs had less change in area ( $46.5 \mathrm{ha})$, in contrast to those in Unprotected areas (184.6 ha), showing the effectiveness of protecting the dune ecosystems and the need to establish regulations and environmental controls for dunes in Unprotected areas (28\%). The central region of the Mexican Caribbean is the most conserved-13\% of this area has low anthropization, and the stable coastline is $75 \%$ unchanged.

\subsection{Environmental Guidelines}

Figure 12 summarizes the results of this study. The greater environmental pressures in the northern region, related to waves, wind, high-intensity hurricanes, high anthropization, and higher nutrient concentrations, cause greater disturbances in the ecosystems in that region. These pressures affect the conservation state and the development of coral reefs, induce shifts in seagrass meadows towards greater relative dominance of less resilient earlier-successional species, create more disturbed mangroves, and cause significant loss to dune area and continuous erosion of the coastal line.

The central and southern regions have more conserved and mature coastal ecosystems. Continuous erosion is not a feature of this coastline, and the degree of anthropization is moderate to low. However, to the south, there are $\delta^{15} \mathrm{~N}$ values that point to wastewater input, which could, in the long term, lead to a shift in the composition and structure of seagrass meadows and coral reefs and increase their vulnerability.

In the northern region, the increasing number of high-intensity hurricanes may cause greater disturbance to the ecosystems, potentially affecting their resilience capacity. There are other pressures on the Mexican Caribbean that cannot be ignored and need to be addressed, such as the effect of Sargassum spp. arrivals on the corals and dune beach systems. Threats to seagrasses have been reported as one of the most urgent issues in recent years $[13,15,16,21]$. 


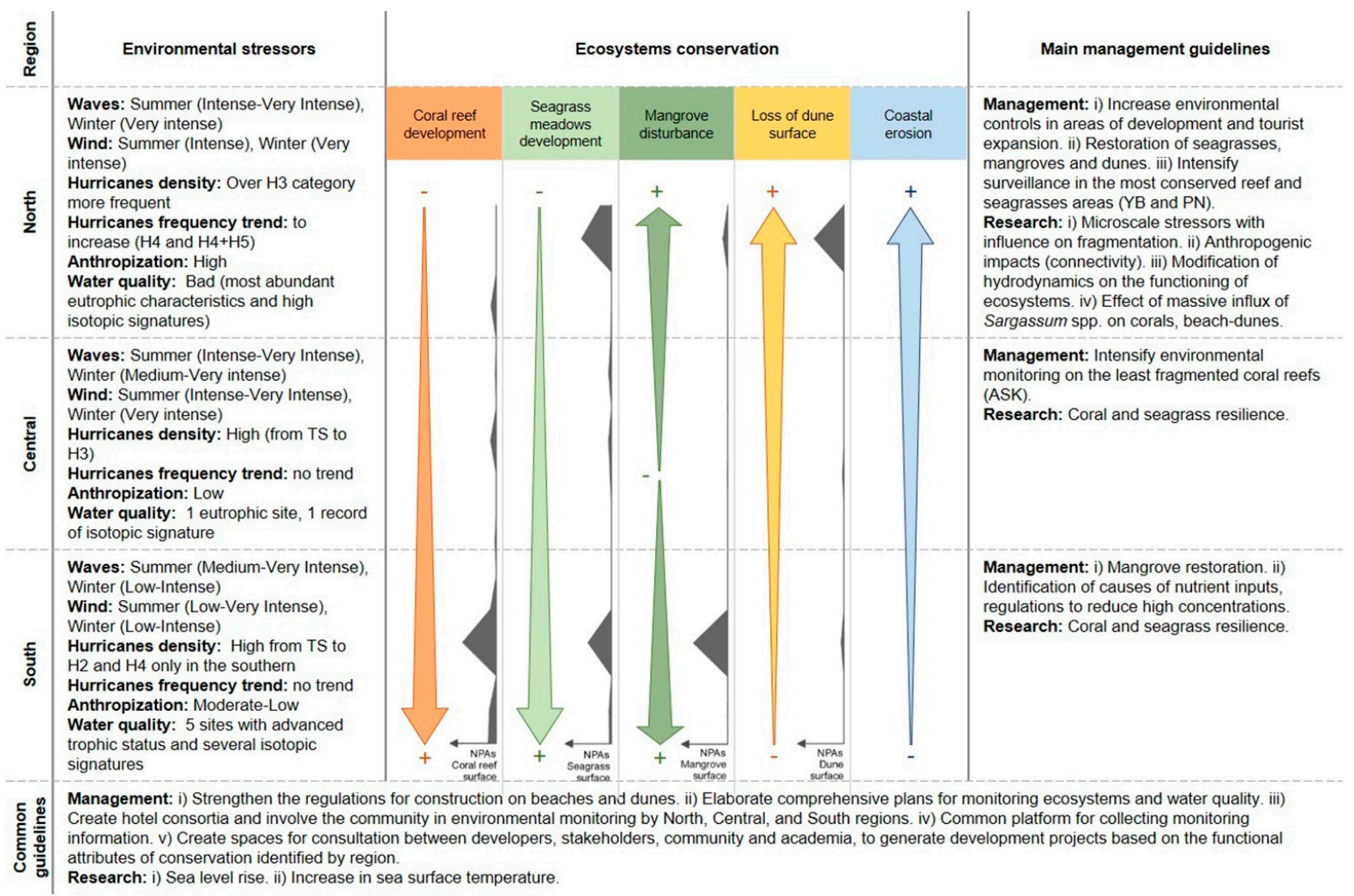

Figure 12. Relationships between environmental pressures, conservation, and protection of ecosystems in the Mexican Caribbean, by region. Management and research guidelines recommended for ecosystems restoration and management.

For the recovery of ecosystems in the Mexican Caribbean, it is important to differentiate management policies according to the needs of each region. Figure 12 identifies the needs for research, as well as lists common guidelines for ecosystem recovery by the regions of the Mexican Caribbean considered in this study.

One environmental guideline that would be useful in the three regions is strengthening building regulations close to beaches and dunes. Encouraging the establishment of hotel consortiums for environmental monitoring and creating a repository of these results with access for managers and academia would also be valuable.

The northern region is where there is most need to increase environmental controls, due to the high degree of anthropization. Carrying out restoration in the most affected ecosystems should be a priority. In the central and southern regions, the water quality needs attention, especially in sites with advanced trophic status. On the other hand, there is also a need to safeguard the less fragmented ecosystems throughout the Mexican Caribbean by intensifying surveillance, especially in the NPAs.

\section{Conclusions}

The conservational status of the coastal ecosystems on the Mexican Caribbean shows a gradient of increasing conservation from north to south, coinciding with the pressures to which they are subjected, both natural (waves, wind, and hurricanes) and anthropic (anthropization and water quality). In the north, the stressors are higher where wave and wind energies are greater, likewise the highest levels of anthropization and bad water quality. These environmental stressors probably affect the development of coral reefs, cause earlier-successional stage seagrasses, the biggest areas of disturbed mangrove and coastal dunes with most loss of area and the greatest coastline erosion.

In addition, the increase in the tracks number of high-intensity hurricanes in the northern region will potentially bring greater pressures and disturbances to the ecosystems, and thereby affect their resilience. Other pressures which impact the ecosystems of the 
Mexican Caribbean, such as disease in the corals and the massive influx of pelagic Sargassum spp., were not addressed in this study.

In terms of protection, most coastal ecosystems are within NPAs, with most in the northern and central regions, particularly YB and SK. However, this is not the case for PMRs, which are probably insufficient, specifically coral reefs and seagrass, e.g., APM and $\mathrm{CO}$ are the areas most affected and they do not have a PMR category.

There is no direct relationship between research interest and the biotope extension in NPAs; there are extensive NPAs in areas with little or no research effort, and vice versa. The fragmentation, or low spatial integrity, of ecosystems is notable in coral reefs, which can induce lower capacity for resistance to disturbances. The least fragmented coral reefs are in YB and ASK. Surveillance and environmental monitoring are strongly recommended in these areas, as they currently have high degrees of conservation.

Management based on environmental guidelines, some common and some differentiated according to the needs of each studied region, is important for the recovery of the ecosystems. The main recommendations concern strengthening environmental controls and regulations for construction on beaches and dunes. Comprehensive effective monitoring programs are also needed. In the northern region, restoration plans for seagrass meadows, mangroves, and dunes are required to improve their conservation status. It is also necessary to intensify surveillance in the NPAs that house the healthiest ecosystems (YB and ASK). Likewise, nutrient inputs should be resolved with consequent effects on the functioning and provision of environmental services in the Mexican Caribbean.

Studies focussed on the impacts of both global change and anthropization on hydrodynamics and connectivity are also required; these include developing observing systems [98] offshore, not just on the coast. Ecosystem services are increasingly at risk and their future functioning will depend on urgent, joint action between academia, government, and developers.

Supplementary Materials: The following are available online at https:/ /www.mdpi.com/2071-105 0/13/5/2738/s1, Table S1: Sampling period and reviewed literature by Natural Protected Area in the Caribbean Mexican.

Author Contributions: Conceptualization, M.G., A.Z.-R. and R.S.; methodology, M.G., A.Z.-R., C.J.C.-R., V.C., I.O., B.I.v.T. and R.S.; formal analysis, M.G., A.Z.-R., C.J.C.-R., V.C., I.O., B.I.v.T. and R.S.; investigation, M.G., A.Z.-R., C.J.C.-R., V.C. and I.O.; data curation, M.G., A.Z.-R., C.J.C.-R., V.C. and I.O.; writing — original draft preparation, M.G., A.Z.-R., C.J.C.-R., V.C. and I.O.; writingreview and editing, M.G., A.Z.-R., C.J.C.-R., V.C., B.I.v.T. and R.S.; visualization, M.G. and R.S.; supervision, project administration and funding acquisition, R.S. All authors have read and agreed to the published version of the manuscript.

Funding: This research was funded by the CONACYT-SENER-Sustentabilidad Energética project: FSE-2014-06-249795 Centro Mexicano de Innovación en Energía del Océano (CEMIE-Océano).

Institutional Review Board Statement: Not applicable.

Informed Consent Statement: Not applicable.

Data Availability Statement: Not applicable.

Acknowledgments: The authors thank the support by CEMIE-Océano (project 249795).

Conflicts of Interest: The authors declare no conflict of interest.

\section{References}

1. Cortés, J. Coral reefs of the Americas: An introduction to Latin American Coral Reefs. In Latin American Coral Reefs; Cortés, J., Ed.; Elsevier Science: Amsterdam, The Netherlands, 2003; pp. 1-7.

2. Agard, J.B.R.; Cropper, A. Caribbean Sea Ecosystem Assessment (CARSEA). Caribb. Mar. Stud. 2007, 8, 1-85.

3. Comisión Nacional de Áreas Naturales Protegidas (CONANP). Áreas Naturales Protegidas Federales de la República ArcGIS Metadata. Available online: http:/ /sig.conanp.gob.mx/website/pagsig/info_shape.htm (accessed on 8 April 2020). 
4. Comisión Nacional de Áreas Naturales Protegidas (CONANP). Actualización de la Cobertura de Vacíos y Omisiones de Conservación en México por las Áreas Protegidas Federales, Estatales y Municipales Hasta 2016. Available online: http: //sig.conanp.gob.mx/website/pagsig/mapas_serie.htm (accessed on 8 April 2020).

5. Rioja-Nieto, R.; Álvarez-Filip, L. Coral reef systems of the Mexican Caribbean: Status, recent trends and conservation. Mar. Pollut. Bull. 2019, 140, 616-625. [CrossRef] [PubMed]

6. Gardner, T.A.; Côté, I.M.; Gill, J.A.; Grant, A.; Watkinson, A.R. Long-term region-wide declines in Caribbean corals. Science 2003, 301, 958-960. [CrossRef] [PubMed]

7. Wilkinson, C. Status of Coral Reefs of the World 2004; Australian Institute Marine Science: Townsville, QLD, Australia, 2004; Volume 1, pp. 1-547.

8. Casarin, R.S.; Martinez, G.R.; Mariño-Tapia, I.; Vanegas, G.P.; Baldwin, E.M.; Mancera, E.E. Manmade Vulnerability of the Cancun Beach System: The Case of Hurricane Wilma. Clean Soil Air Water 2012, 40, 911-919. [CrossRef]

9. Rioja-Nieto, R.; Garza-Pérez, R.; Álvarez-Filip, L.; Mariño-Tapia, I.; Enríquez, C. The Mexican Caribbean: From Xcalak to Holbox, 2nd ed.; Elsevier Ltd.: Amsterdam, The Netherlands, 2018.

10. Knutson, T.; Camargo, S.J.; Chan, J.C.L.; Emanuel, K.; Ho, C.H.; Kossin, J.; Mohapatra, M.; Satoh, M.; Sugi, M.; Walsh, K.; et al. Tropical cyclones and climate change assessment. Bull. Am. Meteorol. Soc. 2019, 100, 1987-2007. [CrossRef]

11. Franks, J.S.; Johnson, D.R.; Ko, D.S.; Rubio, G.S.; Hendon, J.R.; Lay, M. Unprecedented Influx of Pelagic Sargassum along Caribbean Island Coastlines during Summer 2011. Gulf Caribb. Fish. Inst. 2011, 64, 6-8.

12. Smetacek, V.; Zingone, A. Green and golden seaweed tides on the rise. Nature 2013, 504, 84-88. [CrossRef]

13. Silva, R.; Martínez, M.L.; Odériz, I.; Mendoza, E.; Feagin, R.A. Response of vegetated dune-beach systems to storm conditions. Coast. Eng. 2016, 109, 53-62. [CrossRef]

14. Uribe-Martínez, A.; Guzmán-Ramírez, A.; Arreguín-Sánchez, F.; Cuevas, E. El sargazo en el Caribe mexicano, revisión de una historia impensable. In Gobernanza y Manejo de las Costas y Mares Ante la Incertidumbre: Una Guía para Tomadores de Decisiones; RiveraArriaga, E., Azuz-Adeath, I., Rosas, O.D.C., Espinoza-Tenorio, A., Casarín, R.S., Ortega-Rubio, A., Botello, A.V., Vega-Serratos, B.E., Eds.; Universidad Autónoma de Campeche, RICOMAR: Campeche, Mexico, 2020; pp. 743-768.

15. Chávez, V.; Uribe-Martínez, A.; Cuevas, E.; Rodríguez-Martínez, R.E.; van Tussenbroek, B.I.; Francisco, V.; Estévez, M.; Celis, L.B.; Monroy-Velázquez, L.V.; Leal-Bautista, R.; et al. Massive influx of pelagic sargassum spp. on the coasts of the mexican caribbean 2014-2020: Challenges and opportunities. Water 2020, 12, 2908. [CrossRef]

16. van Tussenbroek, B.I.; Hernández Arana, H.A.; Rodríguez-Martínez, R.E.; Espinoza-Avalos, J.; Canizales-Flores, H.M.; GonzálezGodoy, C.E.; Barba-Santos, M.G.; Vega-Zepeda, A.; Collado-Vides, L. Severe impacts of brown tides caused by Sargassum spp. on near-shore Caribbean seagrass communities. Mar. Pollut. Bull. 2017, 122, 272-281. [CrossRef] [PubMed]

17. Rodríguez-Martínez, R.E.; van Tussenbroek, B.; Jordán-Dahlgren, E. Afluencia masiva de sargazo pelágico a la costa del Caribe mexicano (2014-2015). In Florecimientos Algales Nocivos en México, 1st ed.; CICESE: Ensenada, BC, Mexico, 2016; pp. $352-365$.

18. Hewitt, J.E.; Ellis, J.I.; Thrush, S.F. Multiple stressors, nonlinear effects and the implications of climate change impacts on marine coastal ecosystems. Glob. Chang. Biol. 2016, 22, 2665-2675. [CrossRef]

19. Reaka-Kudla, M.L. Biodiversity of Caribbean coral reefs. In Caribbean Marine Biodiversity; Miloslavich, P., Klein, E., Eds.; Des Tech Publishers: Lancaster, CA, USA, 2005; pp. 259-276.

20. van Tussenbroek, B.I. Dynamics of seagrasses and associated algae in coral reef lagoons. Hidrobiologica 2011, 21, $293-310$.

21. van Tussenbroek, B.I.; Cortés, J.; Collin, R.; Fonseca, A.C.; Gayle, P.M.H.; Guzmán, H.M.; Jácome, G.E.; Juman, R.; Koltes, K.H.; Oxenford, H.A.; et al. Caribbean-wide, long-term study of seagrass beds reveals local variations, shifts in community structure and occasional collapse. PLoS ONE 2014, 9, e90600. [CrossRef] [PubMed]

22. Hirales-Cota, M.; Espinoza-Avalos, J.; Schmook, B.; Ruiz-Luna, A.; Ramos-Reyes, R. Drivers of mangrove deforestation in Mahahual-Xcalak, Quintana Roo, southeast Mexico. Ciencias Mar. 2010, 36, 147-159. [CrossRef]

23. Rodríguez-Zúñiga, M.T.; Troche-Souza, C.; Vázquez-Lule, A.D.; Márquez-Mendoza, J.D.; Balderas, B.V.; Valderrama-Landeros, L.; Velázquez-Salazar, S.; Cruz-López, M.I.; Ressl, R.; Uribe-Martínez, A.; et al. Manglares de México/Extensión, Distribución y Monitoreo; Comisión Nacional para el Conocimiento y Uso de la Biodiversidad: Distrito Federal, Mexico, 2013 ; p. 128.

24. Seingier, G.; Espejel, I.; Fermán-Almada, J.L. Cobertura vegetal y marginación en la costa mexicana. Investig. Ambient. 2009, 1, 54-69.

25. Martínez, M.L.; Moreno-Casasola, P.; Espejel, I.; Jiménez-Orocio, O.; Infante Mata, D.; Rodríguez-Revelo, N. Diagnóstico de las Dunas Costeras de México; CONAFOR: Ciudad de Mexico, Mexico, 2014; p. 350.

26. Comisión Nacional para el Conocimiento y Uso de la Biodiversidad (CONABIO). Distribución de los Manglares en México en 2015, Escala: 1:50,000. Edición: 1. Available online: http://www.conabio.gob.mx/informacion/metadata/gis/mx_man15gw. xml?_httpcache=yes\&_xsl=/db/metadata $/$ xsl /fgdc_html.xsl\&_indent=no (accessed on 8 April 2020).

27. Cerdeira-Estrada, S.; Martínez-Clorio, M.I.; Rosique-De-La-Cruz, L.O.; Kolb, M.; Gonzales-Posada, A.M.; Uribe-Martínez, A.; Martell-Dubois, R.; Garza-Pérez, J.R.; Alvarez-Filip, L.; Cruz-López, M.I.; et al. Cobertura Bentónica de los Ecosistemas Marinos del Caribe Mexicano: Cabo Catoche-Xcalak. 2018', escala: 1:8000. edición: 2. Comisión Nacional para el Conocimiento y Uso de la Biodiversidad; Universidad Nacional Autónoma de México. México. Available online: http://www.conabio.gob.mx/ informacion/metadata/gis / covertv2gw.xml?_httpcache=yes\&_xsl=/db/metadata /xsl/fgdc_html.xsl\&_indent=no (accessed on 8 April 2020). 
28. Argüelles-Jiménez, J.; Alva-Basurto, J.C.; Pérez-España, H.; Zetina-Rejón, M.J.; Arias-González, J.E. The measurement of ecosystem development in Caribbean coral reefs through topological indices. Ecol. Indic. 2020, 110, 105866. [CrossRef]

29. Ferdie, M.; Fourqurean, J.W. Responses of seagrass communities to fertilization along a gradient of relative availability of nitrogen and phosphorus in a carbonate environment. Limnol. Oceanogr. 2004, 49, 2082-2094. [CrossRef]

30. Valderrama-Landeros, L.H.; Martell-Dubois, R.; Ressl, R.; Silva-Casarín, R.; Cruz-Ramírez, C.J.; Muñoz-Pérez, J.J. Dynamics of coastline changes in Mexico. J. Geogr. Sci. 2019, 29, 1637-1654. [CrossRef]

31. Maxwell, P.S.; Eklöf, J.S.; van Katwijk, M.M.; O’Brien, K.R.; de la Torre-Castro, M.; Boström, C.; Bouma, T.J.; Krause-Jensen, D.; Unsworth, R.K.F.; van Tussenbroek, B.I.; et al. The fundamental role of ecological feedback mechanisms for the adaptive management of seagrass ecosystems-A review. Biol. Rev. 2017, 92, 1521-1538. [CrossRef]

32. Hernández, A.L.M.; van Tussenbroek, B.I. Patch dynamics and species shifts in seagrass communities under moderate and high grazing pressure by green sea turtles. Mar. Ecol. Prog. Ser. 2014, 517, 143-157. [CrossRef]

33. Hersbach, H.; Bell, B.; Berrisford, P.; Hirahara, S.; Horányi, A.; Muñoz-Sabater, J.; Nicolas, J.; Peubey, C.; Radu, R.; Schepers, D.; et al. The ERA5 global reanalysis. Q. J. R. Meteorol. Soc. 2020, 146, 1999-2049. [CrossRef]

34. European Centre for Medium-Range Weather Forecasts (ECMWF). ERA5: Data Documentation. Available online: https: / / confluence.ecmwf.int/display/CKB/ERA5\%3A+data+documentation (accessed on 8 September 2020).

35. National Oceanic and Atmospheric Administration (NOAA). International Best Track Archive for Climate Stewardship (IBTrACS). Available online: https:/ / www.ncei.noaa.gov/data/international-best-track-archive-for-climate-stewardship-ibtracs/v04r00/ access/shapefile/ (accessed on 3 December 2020).

36. Hirsch, R.M.; Slack, J.R.; Smith, R.A. Techniques of trend analysis for monthly water quality data. Water Resour. Res. 1982, 18, 107-121. [CrossRef]

37. Westmacott, J.R.; Burn, D.H. Climate change effects on the hydrologic regime within the Churchill-Nelson River Basin. J. Hydrol. 1997, 202, 263-279. [CrossRef]

38. Sen, P.K. Estimates of the Regression Coefficient Based on Kendall's Tau. J. Am. Stat. Assoc. 1968, 63, 1379-1389. [CrossRef]

39. Yue, S.; Wang, C. The Mann-Kendall Test Modified by Effective Sample Size to Detect Trend in Serially Correlated Hydrological Series. Water Resour. Manag. 2004, 18, 201-218. [CrossRef]

40. Comisión Nacional del Agua (CONAGUA). Calidad del agua en México. Available online: https://www.gob.mx/conagua/ articulos / calidad-del-agua (accessed on 2 December 2020).

41. EEA (European Environmental Agency). Nutrients in European Ecosystems. Environmental Assessment Report No. 4; Office for official publications of the European Communities: Copenhagen, Denmark, 1999; p. 155.

42. Cruz, C.J.; Mendoza, E.; Silva, R.; Chávez, V. Assessing Degrees of Anthropization on the Coast of Mexico from Ecosystem Conservation and Population Growth Data. J. Coast. Res. 2019, 92, 136-144. [CrossRef]

43. Barranco, L.M.; Carriquiry, J.D.; Rodríguez-Zaragoza, F.A.; Cupul-Magaña, A.L.; Villaescusa, J.A.; Calderón-Aguilera, L.E. Spatiotemporal variations of live coral cover in the northern Mesoamerican Reef System, Yucatan Peninsula, Mexico. Sci. Mar. 2016, 80, 143-150.

44. Medina-Gómez, I.; Madden, C.J.; Herrera-Silveira, J.; Kjerfve, B. Response of Thalassia Testudinum morphometry and distribution to environmental drivers in a pristine tropical lagoon. PLOS ONE 2016, 11, 1-24.

45. Gutiérrez-Aguirre, M.A.; De La Fuente-Betancourt, M.G.; Cervantes-Martínez, A. Biomasa y densidad de dos especies de pastos marinos en el sur de Quintana Roo, México. Rev. Biol. Trop. 2000, 48, 313-316. [CrossRef]

46. Sánchez, A.; Ortiz-Hernández, M.C.; Talavera-Sáenz, A.; Aguíñiga-García, S. Stable nitrogen isotopes in the turtle grass Thalassia testudinum from the Mexican Caribbean: Implications of anthropogenic development. Estuar. Coast. Shelf Sci. 2013, 135, 86-93. [CrossRef]

47. Sánchez, A.; Anguas-Cabrera, D.; Camacho-Cruz, K.; Ortiz-Hernández, M.C.; Aguíñiga-García, S. Spatial and temporal variation of the $\delta 15 \mathrm{~N}$ in Thalassia testudinum in the Mexican Caribbean (2009-2017). Mar. Freshw. Res. 2020, 71, 905-912. [CrossRef]

48. Mutchler, T.; Dunton, K.H.; Townsend-Small, A.; Fredriksen, S.; Rasser, M.K. Isotopic and elemental indicators of nutrient sources and status of coastal habitats in the Caribbean Sea, Yucatan Peninsula, Mexico. Estuar. Coast. Shelf Sci. 2007, 74, 449-457. [CrossRef]

49. Mutchler, T.; Mooney, R.; Wallace, S.; Podsim, L.; Fredriksen, S.; Dunton, K. Origins and Fate of Inorganic Nitrogen from Land to Coastal Ocean on the Yucatan Peninsula, Mexico. Coast. Lagoons 2010, 12, 283-305.

50. Odériz, I.; Gómez, I.; Ventura, Y.; Díaz, V.; Escalante, A.; Gómez, D.T.; Bouma, T.J.; Silva, R. Understanding Drivers of Connectivity and Resilience under Tropical Cyclones in Coastal Ecosystems at Puerto Morelos, Mexico. J. Coast. Res. 2020, 95, 128-132. [CrossRef]

51. Mendoza, E.; Odériz, I.; Martínez, M.L.; Silva, R. Measurements and Modelling of Small Scale Processes of Vegetation Preventing Dune Erosion. J. Coast. Res. 2017, 77, 19-27. [CrossRef]

52. Guimarais, M.; Zúñiga, A.; Pina, F.; Matos, F. Hurricane Paloma's effects on seagrasses along Jardines de la Reina archipelago, Cuba. Rev. Biol. Trop. 2013, 61, 1425-1432.

53. Montefalcone, M.; Parravicini, V.; Vacchi, M.; Albertelli, G.; Ferrari, M.; Morri, C.; Bianchi, C.N. Human influence on seagrass habitat fragmentation in NW Mediterranean Sea. Estuar. Coast. Shelf Sci. 2010, 86, 292-298. [CrossRef]

54. El Allaoui, N.; Serra, T.; Colomer, J.; Soler, M.; Casamitjana, X.; Oldham, C. Interactions between fragmented seagrass canopies and the local hydrodynamics. PLoS ONE 2016, 11, 1-19. [CrossRef] 
55. Cruz-Palacios, V.; van Tussenbroek, B.I. Simulation of hurricane-like disturbances on a Caribbean seagrass bed. J. Exp. Mar. Biol. Ecol. 2005, 324, 44-60. [CrossRef]

56. James, R.K.; Silva, R.; van Tussenbroek, B.I.; Escudero-Castillo, M.; Mariño-Tapia, I.; Dijkstra, H.A.; Van Westen, R.M.; Pietrzak, J.D.; Candy, A.S.; Katsman, C.A.; et al. Maintaining Tropical Beaches with Seagrass and Algae: A Promising Alternative to Engineering Solutions. Bioscience 2019, 69, 136-142. [CrossRef]

57. Boehlert, G.W. Larval dispersal and survival in tropical reef fishes. In Reef Fisheries; Polunin, N.V.C., Roberts, C.M., Eds.; Fish and Fisheries Series; Chapman \& Hall: London, UK, 1996; Volume 20, pp. 61-84.

58. Alcérreca-Huerta, J.C.; Encarnacion, J.I.; Ordoñez-Sánchez, S.; Callejas-Jiménez, M.; Barroso, G.G.D.; Allmark, M.; Mariño-Tapia, I.; Casarín, R.S.; O’Doherty, T.; Johnstone, C.; et al. Energy yield assessment from ocean currents in the insular shelf of Cozumel Island. J. Mar. Sci. Eng. 2019, 7, 147. [CrossRef]

59. Van Dijk, J.K.; van Tussenbroek, B.I.; Jiménez-Durán, K.; Márquez-Guzman, G.J.; Ouborg, J. High levels of gene flow and low population genetic structure related to high dispersal potential of a tropical marine angiosperm. Mar. Ecol. Prog. Ser. 2009, 390, 67-77. [CrossRef]

60. Porto-Hannes, I.; Zubillaga, A.L.; Shearer, T.L.; Bastidas, C.; Salazar, C.; Coffroth, M.A.; Szmant, A.M. Population structure of the corals Orbicella faveolata and Acropora palmata in the Mesoamerican Barrier Reef System with comparisons over Caribbean basin-wide spatial scale. Mar. Biol. 2015, 162, 81-98. [CrossRef]

61. Carriquiry, D.J.; Barranco-Servin, M.L.; Villaescusa, A.J.; Camacho-Ibar, F.V.; Reyes-Bonilla, H.; Cupul-Magaña, L.A. Conservation and Sustainability of Mexican Caribbean Coral Reefs and the Threats of a Human-Induced Phase-Shift. In Environmental Change Sustainability; Silvern, S., Young, S., Eds.; InTech: London, UK, 2013; pp. 29-51.

62. Camacho-Cruz, K.A.; Ortiz-Hernández, M.C.; Sánchez, A.; Carrillo, L.; De Jesús Navarrete, A. Water quality in the eastern karst region of the Yucatan Peninsula: Nutrients and stable nitrogen isotopes in turtle grass, Thalassia testudinum. Environ. Sci. Pollut. Res. 2020, 27, 15967-15983. [CrossRef]

63. Ladd, M.C.; Collado-Vides, L. Practical applications of monitoring results to improve managing for coral reef resilience: A case study in the Mexican Caribbean. Biodivers. Conserv. 2013, 22, 1591-1608. [CrossRef]

64. van Tussenbroek, B.; Hermus, K.; Tahey, T. Biomass and Growth of the Turtle Grass Thalassia testudinum (Banks ex Koníg) in a Shallow Tropical Lagoon System, in Relation to Tourist Development. Caribb. J. Sci. 1996, 32, 357-364.

65. Hernández-Terrones, L.; Rebolledo-Vieyra, M.; Merino-Ibarra, M.; Soto, M.; Le-Cossec, A.; Monroy-Ríos, E. Groundwater pollution in a karstic region (NE Yucatan): Baseline nutrient content and flux to coastal ecosystems. Water Air Soil Pollut. 2011, 218, 517-528. [CrossRef]

66. Carruthers, T.J.B.; van Tussenbroek, B.I.; Dennison, W.C. Influence of submarine springs and wastewater on nutrient dynamics of Caribbean seagrass meadows. Estuar. Coast. Shelf Sci. 2005, 64, 191-199. [CrossRef]

67. Lapointe, B.E.; Langton, R.; Bedford, B.J.; Potts, A.C.; Day, O.; Hu, C. Land-based nutrient enrichment of the Buccoo Reef Complex and fringing coral reefs of Tobago, West Indies. Mar. Pollut. Bull. 2010, 60, 334-343. [CrossRef] [PubMed]

68. Lapointe, B.E.; Littler, M.M.; Littler, D.S. A comparison of nutrient-limited productivity in macroalgae from a Caribbean barrier reef and from a mangrove ecosystem. Aquat. Bot. 1987, 28, 243-255. [CrossRef]

69. Lapointe, B.E. Nutrient thresholds for bottom-up control of macroalgal blooms on coral reefs in Jamaica and southeast Florida. Limnol. Oceanogr. 1997, 42, 1119-1131. [CrossRef]

70. Mumby, P.J. The impact of exploiting grazers (Scaridae) on the dynamics of Caribbean coral reefs. Ecol. Appl. 2006, 16, 747-769. [CrossRef]

71. Burkepile, D.E.; Hay, M.E. Herbivore species richness and feeding complementarity affect community structure and function on a coral reef. Proc. Natl. Acad. Sci. USA 2008, 105, 16201-16206. [CrossRef] [PubMed]

72. Suchley, A.; McField, M.D.; Alvarez-Filip, L. Rapidly increasing macroalgal cover not related to herbivorous fishes on Mesoamerican reefs. PeerJ 2016, 4, e2084. [CrossRef]

73. Duarte, C.M.; Martín, M.; Margarita, G. Evidence of iron deficiency in seagrasses growing above carbonate sediments. Limnol. Oceanogr. 1995, 40, 1153-1158. [CrossRef]

74. Moore, K.A.; Wetzel, R.L. Seasonal variations in eelgrass (Zostera marina L.) responses to nutrient enrichment and reduced light availability in experimental ecosystems. J. Exp. Mar. Biol. Ecol. 2000, 244, 1-28. [CrossRef]

75. Silberstein, K.; Chiffings, A.W.; McComb, A.J. The loss of seagrass in cockburn sound, Western Australia. III. The effect of epiphytes on productivity of Posidonia australis Hook. F. Aquat. Bot. 1986, 24, 355-371. [CrossRef]

76. Tomasko, D.A.; Lapointe, B.E. Productivity and biomass of Thalassia testudinum as related to water column nutrient availability and epiphyte levels: Field observations and experimental studies. Mar. Ecol. Prog. Ser. 1991, 75, 9-17. [CrossRef]

77. Lapointe, B.E.; Tomasko, D.A.; Matzie, W.R. Eutrophication and trophic state classification of seagrass communities in the Florida Keys. Bull. Mar. Sci. 1994, 54, 696-717.

78. Suchley, A.; Alvarez-Filip, L. Local human activities limit marine protection efficacy on Caribbean coral reefs. Conserv. Lett. 2018, 11, e12571. [CrossRef]

79. Denny, M.W. Biology and the Mechanics of the Wave-Swept Environment; Princeton University Press: Princeton, NJ, USA, 1988; p. 329.

80. Koch, E.W.; Gust, G. Water flow in tide- and wave-dominated beds of the seagrass Thalassia testudinum. Mar. Ecol. Prog. Ser. 1999, 184, 63-72. [CrossRef] 
81. Wenger, A.S.; Williamson, D.H.; da Silva, E.T.; Ceccarelli, D.M.; Browne, N.K.; Petus, C.; Devlin, M.J. Effects of reduced water quality on coral reefs in and out of no-take marine reserves. Conserv. Biol. 2016, 30, 142-153. [CrossRef] [PubMed]

82. Pollock, F.J.; Lamb, J.B.; Field, S.N.; Heron, S.F.; Schaffelke, B.; Shedrawi, G.; Bourne, D.G.; Willis, B.L. Sediment and turbidity associated with offshore dredging increase coral disease prevalence on nearby reefs. PLoS ONE 2014, 9, e102498. [CrossRef] [PubMed]

83. Walker, D.I.; Carruthers, T.J.B.; Morrison, P.F.; McComb, A.J. Experimental manipulation of canopy density in a temperate seagrass Amphibolis griffithii (Black) den Hartog] meadow: Effects on sediments. In Seagrass Biology; Kuo, J., Phillips, R.C., Walker, D.I., Kirkman, H., Eds.; Proceedings of an International Workshop; University of Western Australia: Nedlans, WA, Australia, 1996; pp. 117-122.

84. Creed, J.C.; Amado Filho, G.M. Disturbance and recovery of the macroflora of a seagrass (Halodule wrightii Ascherson) meadow in the Abrolhos Marine National Park, Brazil: An experimental evaluation of anchor damage. J. Exp. Mar. Biol. Ecol. 1999, 235, 285-306. [CrossRef]

85. Orth, R.J.; Fishman, J.R.; Wilcox, D.J.; Moore, K.A. Identification and Management of Fishing Gear Impacts in a Recovering Seagrass System in the Coastal Bays of the Delmarva Peninsula, USA. J. Coast. Res. 2002, 111-129.

86. Pérez-Villegas, G.; Carrascal, E. Tourism development in Cancun, Quintana Roo and its consequences on vegetation. Investig. Geogr. 2000, 43, 145-166.

87. Pethick, J.; Ruitenbeek, J. Coastal Geomorphology and Climate Change Adaptation. In Opportunities for Environmentally Healthy, Inclusive, and Resilient Growth in Mexico's Yucatán Peninsula; Sánchez-Triana, E., Ruitenbeek, J., Enriquez, S., Siegmann, K., Eds.; International Development in Focus/World Bank Group: Washington, DC, USA, 2020; pp. 23-40.

88. Bozec, Y.M.; Alvarez-Filip, L.; Mumby, P.J. The dynamics of architectural complexity on coral reefs under climate change. Glob. Chang. Biol. 2015, 21, 223-235. [CrossRef] [PubMed]

89. Rodríguez-Zaragoza, F.A.; Ortiz, M.; Berrios, F.; Campos, L.; De Jesús-Navarrete, A.; Castro-Pérez, J.; Hernández-Flores, A.; García-Rivas, M.; Fonseca-Peralta, F.; Gallegos-Aguilar, E. Trophic models and short-term dynamic simulations for benthic-pelagic communities at banco chinchorro biosphere reserve (Mexican Caribbean): A conservation case. Community Ecol. 2016, 17, 48-60. [CrossRef]

90. Sleeman, J.C.; Kendrick, G.A.; Boggs, G.S.; Hegge, B.J. Measuring fragmentation of seagrass landscapes: Which indices are most appropriate for detecting change? Mar. Freshw. Res. 2005, 56, 851-864. [CrossRef]

91. Alvarez-Filip, L.; Estrada-Saldívar, N.; Pérez-Cervantes, E.; Molina-Hernández, A.; González-Barrios, F.J. A rapid spread of the stony coral tissue loss disease outbreak in the Mexican Caribbean. PeerJ 2019, 7, e8069. [CrossRef]

92. Unsworth, R.K.F.; Collier, C.J.; Waycott, M.; Mckenzie, L.J.; Cullen-Unsworth, L.C. A framework for the resilience of seagrass ecosystems. Mar. Pollut. Bull. 2015, 100, 34-46. [CrossRef] [PubMed]

93. Bell, S.S.; Fonseca, M.S.; Stafford, N.B. Seagrass ecology: New contributions from a landscape perspective. In Seagrasses: Biology, Ecology and Conservation; Larkum, A.W.D., Orth, R., Duarte, C.M., Eds.; Springer: Dordrecht, The Netherlands, 2006; pp. 625-645.

94. Duarte, C.M.; Fourqurean, J.W.; Krause-Jensen, D.; Olesen, B. Dynamics of Seagrass Stability and Change. In Seagrasses: Biology, Ecology and Conservation; Larkum, A.W.D., Orth, R., Duarte, C.M., Eds.; Springer: Dordrecht, The Netherlands, 2006; pp. $271-294$.

95. Brenner, L.; Engelbauer, M.; Job, H. Mitigating tourism-driven impacts on mangroves in Cancún and the Riviera Maya, Mexico: An evaluation of conservation policy strategies and environmental planning instruments. J. Coast. Conserv. 2018, 22, 755-767. [CrossRef]

96. Vázquez-Lule, A.D.; Díaz-Gallegos, J.; Adame, M.F. Caracterización del sitio de manglar Cozumel. In Sitios de Manglar con Relevancia Biológica y con Necesidades de Rehabilitación Ecológica; Comisión Nacional para el Conocimiento y Uso de la Biodiversidad (CONABIO): Distrito Federal, Mexico, 2009; pp. 1-17.

97. Cinco-Castro, S.; Herrera-Silveira, J. Vulnerability of mangrove ecosystems to climate change effects: The case of the Yucatan Peninsula. Ocean Coast. Manag. 2020, 192, 105196. [CrossRef]

98. Liu, Y.; Kerkering, H.; Weisberg, R.H. Coastal Ocean Observing Systems; Elsevier: London, UK, $2015 ;$ pp. 1-461. 